\title{
Article \\ Characterization of Supplementary Cementitious Materials and Fibers to Be Implemented in High Temperature Concretes for Thermal Energy Storage (TES) Application
}

\author{
Laura Boquera ${ }^{1,2}{ }^{\mathbb{D}}$, David Pons ${ }^{3}$, Ana Inés Fernández ${ }^{3}$ (D) and Luisa F. Cabeza ${ }^{2, *(D)}$ \\ 1 CIRIAF-Interuniversity Research Centre on Pollution and Environment Mauro Felli, Via G. Duranti 63, \\ 06125 Perugia, Italy; laura.boquera@udl.cat \\ 2 GREiA Research Group, Universitat de Lleida, Pere de Cabrera s/n, 25001 Lleida, Spain \\ 3 Departament de Ciència de Materials i Química Física, Ciència i Enginyeria de Materials, \\ Universitat de Barcelona, Martí i Franquès 1, 08028 Barcelona, Spain; davidpons2011@gmail.com (D.P.); \\ ana_inesfernandez@ub.edu (A.I.F.) \\ * Correspondence: luisaf.cabeza@udl.cat
}

\section{check for} updates

Citation: Boquera, L.; Pons, D.; Fernández, A.I.; Cabeza, L.F. Characterization of Supplementary Cementitious Materials and Fibers to Be Implemented in High Temperature Concretes for Thermal Energy Storage (TES) Application. Energies 2021, 14, 5190. https://doi.org/ $10.3390 /$ en14165190

Academic Editors: Gino Bella and Antonio Zuorro

Received: 21 July 2021

Accepted: 19 August 2021

Published: 22 August 2021

Publisher's Note: MDPI stays neutral with regard to jurisdictional claims in published maps and institutional affiliations.

Copyright: (c) 2021 by the authors. Licensee MDPI, Basel, Switzerland. This article is an open access article distributed under the terms and conditions of the Creative Commons Attribution (CC BY) license (https:// creativecommons.org/licenses/by/ $4.0 /)$.

\begin{abstract}
Six supplementary cementitious materials (SCMs) were identified to be incorporated in concrete exposed to high-temperature cycling conditions within the thermal energy storage literature. The selected SCMs are bauxite, chamotte, ground granulated blast furnace slag, iron silicate, silica fume, and steel slag. A microstructural characterization was carried out through an optical microscope, X-ray diffraction analysis, and FT-IR. Also, a pozzolanic test was performed to study the reaction of SCMs silico-aluminous components. The formation of calcium silica hydrate was observed in all SCMs pozzolanic test. Steel slag, iron silicate, and ground granulated blast furnace slag required further milling to enhance cement reaction. Moreover, the tensile strength of three fibers (polypropylene, steel, and glass fibers) was tested after exposure to an alkalinity environment at ambient temperature during one and three months. Results show an alkaline environment entails a tensile strength decrease in polypropylene and steel fibers, leading to corrosion in the later ones.
\end{abstract}

Keywords: supplementary cementitious materials; fibers; thermal energy storage; sensible heat storage technology; concrete

\section{Introduction}

Depletion of fossil fuel energy sources is becoming every day a noteworthy problem, both its environmental impact generated and the technology dependence on fossil energy [1]. Renewable energies are thriving to reduce climate change consequences, in particular solar energy. Sunlight is globally available, easy to harvest, and being able to frame the solar radiation hours in relation to the location [2,3]. Among the different technology options to harness solar energy, concentrating solar power is one of them, which converts the heating generated by the sun into electricity. One drawback of solar energy is that when the sun sets or the meteorological conditions are not favorable, the energy demand cannot be covered, leading to the implementation of thermal energy storage tanks in concentrating solar power (CSP) plants to ensure continuous energy demand $[4,5]$.

So far, cutting edge energy storage sensible heat materials were studied, highlighting in CSP applications the commonly used molten salts [6,7]. In this context, are distinguished two possible storage media materials, in liquid and solid. When considering a liquid media, hot and cold layers are separated in the tank, storing and releasing the heat. Molten salts, water, and synthetic oil are some examples of liquid media. On the other hand, in a stable solid media, ceramics and metals are identified as suitable materials [8]. Also, within potential sensible heat storage (SHS) materials, concrete shows attractive properties to be used as thermal energy storage materials at high temperature [9]. 
Concrete is a composite construction material having a cementitious matrix and aggregates as filler. This ancient material is commonly used for structural purposes in buildings and civil works. For this reason, the interest in improving the properties of concrete has always been a challenge. As a ceramic material, concrete can achieve high compressive strength, while tensile strength is poor and cracks are generated. In addition, concrete has a well-known range of service temperatures, and it does not have good behavior at temperatures higher than $400{ }^{\circ} \mathrm{C}$, which would be of interest for its use in CSP plants, as stated by several authors $[9,10]$.

The composition of concrete could be complemented by adding supplementary cementitious materials (SCMs) as a partial cement replacement. These materials have a powder format, usually lower or equivalent to cement fineness, with high siliceous and aluminous components [11]. To be considered as an optimal SCM they should have hydraulic or pozzolanic properties. Some SCMs have hydraulic potential, which are capable of setting and hardening under water. In comparison, others are complementary and have higher pozzolanic properties, ensuring the key reaction of silico-aluminous components with lime (calcium hydroxide) [12].

During the pozzolanic reaction (usually an irreversible process) a strong cementing matrix is formed involving dissolved silicic acid, water, and $\mathrm{CaO}$ or $\mathrm{Ca}(\mathrm{OH})_{2}$ or other. For this reaction to happen, enough free calcium ion and a high $\mathrm{pH}$ of 12 and above are needed [13].

SCMs are added into the mixture during the concrete elaboration in order to improve or achieve certain properties, either in fresh or hardened state. In the European Standard EN 197-1:2011 [14], some SCMs—such as fly ash, silica fume, pozzolana, etc.-are regulated. Most part of deployed SCMs come as a by-product from coal, iron and steel making industries. Despite widespread of the standard recognized SCM, there are others with equivalent potential, which are lesser known, like volcanic ash, natural pozzolanas and biomass ash. As stated by Snelling et al. [12], the use of SCM or its partial replacement of cement represent three main advantages. SCM valorization renders an economic saving and lower environmental impact resulting from cement content reduction in the mixture. In addition, the final blending product obtains enhanced durability. Interest growth on this material shows up as high $\mathrm{CO}_{2}$ emissions are reported from cement production. Clinkerization process accounts up to $8 \%$ of global $\mathrm{CO}_{2}$ emissions [15]. Solutions need to be considered reducing cement dependence to meet Paris Agreement climate change statements. Partially substitute cement with pozzolanic materials rose attention as cement alternative, forming a cement blend. Since cement production has a high environmental impact, the incorporation of SCM entails the reduction of cement content.

Beside the intrinsic properties of the SCM, other important factors will influence its characteristics and performance in concrete blend. Mixing design will be of great importance, with water binder ratio being a key parameter. During mixture preparation, in fresh state (hydration of the mixture), curing temperature will affect the workability and setting time. Once in hardened state, properties will be highly depending on volume porosity (pore structure), influencing the mechanical strength [13].

Table 1 presents a literature overview containing SCM in concrete for TES to be used as storage media in CSP plants. In all the publications weight percentage of the SCM is presented as well as the dosage content $\left(\mathrm{kg} / \mathrm{m}^{3}\right)$. Whereas the composition or characterization of the SCM is rarely specified or analyzed. Fly ash and silica fume, and the combination of both SCM are the widespread ones in concrete mixtures, followed by ground granulated blast furnace slag. 
Table 1. SCM used in concrete for TES in CSP plant application

\begin{tabular}{|c|c|c|c|c|c|c|c|c|c|c|}
\hline Type of SCM & $\stackrel{\%}{\text { SCM }}$ & $\underset{\mathrm{SCM}}{\mathrm{kg} / \mathrm{m}^{3}}$ & $\begin{array}{c}\mathrm{kg} / \mathrm{m}^{3} \\
\text { Cement }\end{array}$ & $\begin{array}{l}\text { Cement } \\
\text { Type }\end{array}$ & $\begin{array}{l}\text { Particle Size } \\
\text { Distribution }\end{array}$ & $\begin{array}{l}\text { Chemical } \\
\text { Composition }\end{array}$ & XRD & TG & $\begin{array}{l}\text { Maximum } \\
\text { Temperature } \\
\left({ }^{\circ} \mathrm{C}\right)\end{array}$ & Reference \\
\hline \multirow{7}{*}{ Fly ash } & 40 & 214 & 320 & \multirow{4}{*}{ CAC } & - & - & - & - & & \multirow{6}{*}{ [16] } \\
\hline & 50 & 265 & 265 & & - & - & - & - & & \\
\hline & 60 & 320 & 214 & & - & - & - & - & & \\
\hline & 70 & 374 & 160 & & - & - & - & - & 600 & \\
\hline & 50 & 193 & 193 & \multirow{2}{*}{ OPC } & - & - & - & - & & \\
\hline & 70 & 249 & 107 & & - & - & - & - & & \\
\hline & 43 & 160 & 210 & OPC & - & - & - & - & 600 & {$[17,18]$} \\
\hline $\begin{array}{l}\text { Ground granulated } \\
\text { blast furnace slag }\end{array}$ & 30 & & & CAC & yes & yes & yes & yes & 550 & [19] \\
\hline \multirow{2}{*}{ Silica fume } & 10 & 66 & 596 & OPC & - & - & - & - & 600 & [10] \\
\hline & - & & & & - & - & - & - & 600 & [20] \\
\hline \multirow{2}{*}{$\begin{array}{l}\text { Fly ash } \\
\text { Silica fume }\end{array}$} & $\begin{array}{l}56 \\
11\end{array}$ & $\begin{array}{c}267 \\
54\end{array}$ & 214 & CAC & - & - & - & - & 600 & \multirow{2}{*}{ [16] } \\
\hline & 47 & 160 & 178 & OPC & - & - & - & - & 600 & \\
\hline $\begin{array}{l}\text { Silica micro powder } \\
\text { Aluminum powder }\end{array}$ & - & - & - & CAC & - & yes & - & - & 1100 & [21] \\
\hline
\end{tabular}

John et al. [16] demonstrated that depending on the cement used in the concrete mixture, silica fume contributed or not to compressive strength. For instance, needs calcium hydroxide to contribute in compressive strength. Therefore, the combination of silica fume with calcium aluminate cement can contribute in other physical properties, such as bulk density. The same article states that a combination of fly ash and silica fume with Portland cement gives a higher refractory performance to the concrete mixture in a ternary binder. In another research, Alonso et al. [19] added ground granulated blast furnace slag (GGBFS) to control any risk or early conversion of calcium aluminate cement. Bauxite powder, silica micro powder, and aluminum micro powder were used by Chengzhou et al. [21] to improve refractory and thermal conductivity properties.

Moreover, characterization of industry by-products was previously studied to be used as thermal energy storage material by itself [22-25].

On the other hand, to compensate the flexural strength of concrete, fibers are included in concrete formulations. Fibers are materials that are being used for 4000 years ago as an addition to improve the properties of raw material. As an example, in lower Mesopotamia, the mud bricks cooked under the sun were modified with straw and, until some years ago goat and horsehair were used to modify the gypsum. The 'fibrocement' was composed of cement paste in which were added with $8-16 \%$ of asbestos fibers to improve 2 or 4 times the bending strength. Synthetic fibers are also used since they are industrially produced in 1935 [26]. The first evidence of fiber reinforced concrete was in the 1960s, to solve concrete cracks generated by shrinkage [27-29].

The main goal of using fibers is to increase the structural properties and to prevent or mitigate the spalling effect, which is produced in the concrete when it is heated up to high temperatures [27]. The incorporation of fibers in the concrete increases the cracks resistance and the fragility is reduced. Simultaneously, the increment of the fracture toughness of the material is noticed, improving the absorption of energy while the plastic deformation without a cracking takes place. The objective is to achieve a concrete with fibers highly appropriate to support dynamic actions or to prevent cracking control situations [30].

In the context of concrete for thermal energy storage applied in CSP power plants, several types of fibers were used for different purposes. Polymeric fibers [31] were added to reduce the spalling effect generated at high temperatures. In contrast, metal fibers have twofold roles: sewing the fissures and enhancing at the same time the thermal conductivity of the material. Having a close look at concrete literature to be used as TES at medium-high temperatures, an overview of fiber types used is summarized in Table 2. Typically, steel and propylene fibers are used, but Ozger et al. [31] and Girardi et al. [32] pursued recycled fibers. Previous authors considered the combination of both fiber types to take advantage of each fiber performance. 
Table 2. Types and characteristics of fibers used in concrete for TES in CSP plant application

\begin{tabular}{|c|c|c|c|c|c|c|c|}
\hline Type of Fibers & Diameter & $\begin{array}{l}\text { Length } \\
\text { (mm) }\end{array}$ & $\begin{array}{l}\text { Tensile Strength } \\
\text { of the Fiber (MPa) }\end{array}$ & $\begin{array}{c}\text { Melting } \\
\text { Temperature } \\
\left({ }^{\circ} \mathrm{C}\right)\end{array}$ & Density & $\begin{array}{c}\text { Weight in } \\
\text { Concrete }\left(\mathrm{kg} / \mathrm{m}^{3}\right)\end{array}$ & Reference \\
\hline Polypropylene fibers & $33 \mu \mathrm{m}$ & $\begin{array}{c}6 \\
24\end{array}$ & 450 & $\begin{array}{l}- \\
-\end{array}$ & $\begin{array}{l}- \\
-\end{array}$ & $\begin{array}{l}- \\
-\end{array}$ & [33] \\
\hline $\begin{array}{l}\text { Nylon polyamide } \\
\text { PA66 fibers }\end{array}$ & $38-41 \mu \mathrm{m}$ & $8 \pm 3$ & $286 \pm 38$ & 285 & $13-15$ dtex & - & {$[31,32]$} \\
\hline $\begin{array}{l}\text { Metal powders } \\
\text { Steel fibers }\end{array}$ & $\begin{array}{l}12 \mu \mathrm{m} \\
530 \mu \mathrm{m}\end{array}$ & $11 \pm 1$ & $400 \pm 38$ & - & - & - & [32] \\
\hline $\begin{array}{l}\text { Recycled metal } \\
\text { shavings }\end{array}$ & $0.1-0.2 \mathrm{~mm}^{2}$ & $10-30$ & - & - & - & - & \\
\hline Steel fiber & $0.9 \mathrm{~mm}$ & $\begin{array}{l}50 \\
25 \\
10\end{array}$ & - & - & - & 0.2 & {$[34,35]$} \\
\hline PP fibers & $18 \mu \mathrm{m}$ & 12.7 & - & - & - & - & [16] \\
\hline Steel fibers & - & - & - & - & - & 2 & {$[10,16,36]$} \\
\hline
\end{tabular}

Nevertheless, from Table 2, insufficient information is given of the type of fibers and their characteristics, which request to further study the fibers that could be added in concrete under high thermal cycle conditions.

The addition of the supplementary cementitious materials involves a chemical reaction in the presence of water, ensuring long term durability and, generally, increasing the resistance to alkali-aggregate reaction $[37,38]$. Whilst, fibers are used to control plastic shrinkage as well as internal tensile forces, under high-temperature exposure avoids the deterioration of concrete material. Therefore, great attention should be paid to determine the appropriate characteristics of the fibers and the supplementary cementitious materials, such as morphology and physical properties (size, shape, density, surface characteristics).

Considering a future use in indirect thermal energy storage system (using heat exchangers), the aim of this research is to characterize fibers and supplementary cementitious materials to be potentially implemented in high-temperature concrete to improve its performance. Mechanical and chemical characterization of fibers and supplementary cementitious materials was evaluated.

\section{Materials and Methods}

\subsection{Materials}

The materials used in this research are fifteen types of fibers, divided in four families: polypropylene fibers, tire pneumatic fibers, glass fibers, and metal fibers. Moreover, seven types of SCMs are also considered.

The SCMs used in this study are shown in Figure 1 and their chemical composition as provided by their data sheets are presented in Table 3. In this research, four out of the seven selected supplementary cementitious materials are by-products coming from industries. Ground granulated blast furnace (GGBFS), iron silicate (IS), silica fume (SF), and steel slag (SS), are residues from the steel and iron industry. Additionally, to have a variety of materials, two refractory materials were selected to analyze their potential, bauxite (BAU), and chamotte (CHA).

Bauxite is a sedimentary rock with high alumina $\left(\mathrm{Al}_{2} \mathrm{O}_{3}\right)$ content, used in aluminum production. The bauxite sample used in this research has a gibbsite origin and was previously calcined in a rotary kiln and later milled to achieve a fine powder. The other refractory material is chamotte, also known as grog. This comes from kaolin ore calcination and subsequently milling process. As it can be appreciated in Table 3 , chamotte alumina content is $40 \%$, nearly half of the bauxite. Both materials come from the same enterprise, Arciresa, arcillas refractarias S.A. (Spain). 


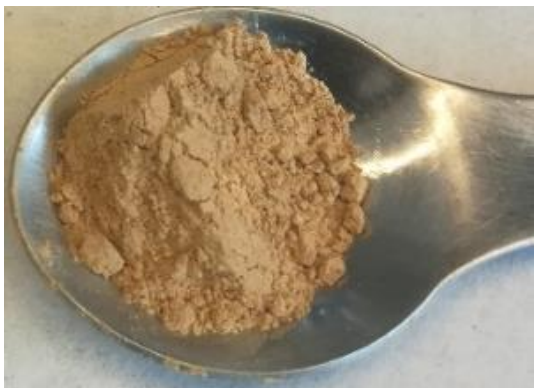

(a)

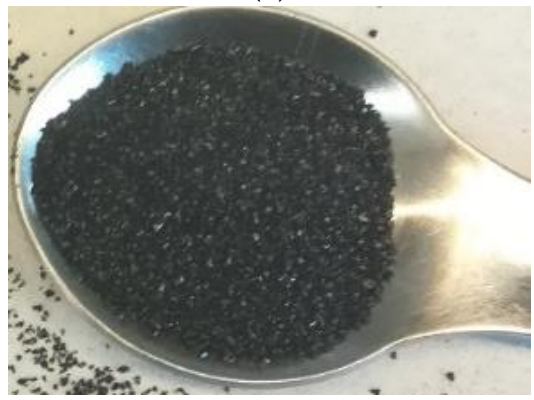

(d)

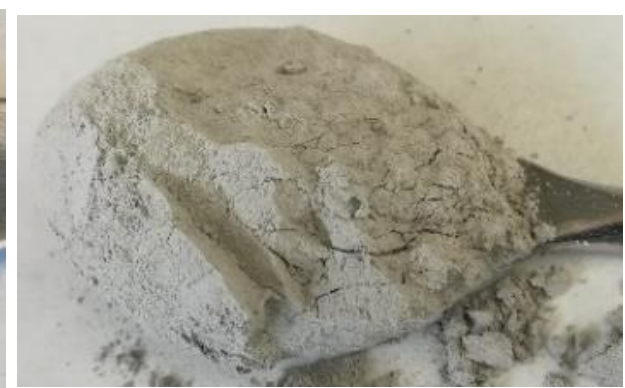

(b)

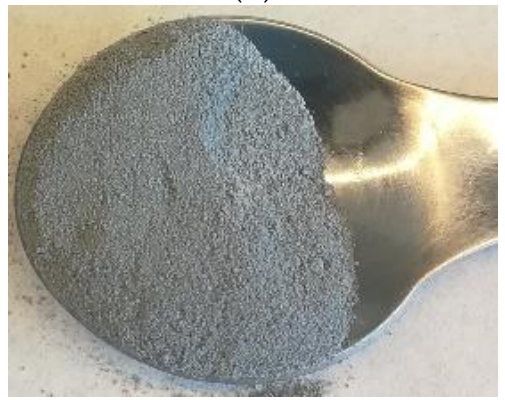

(e)

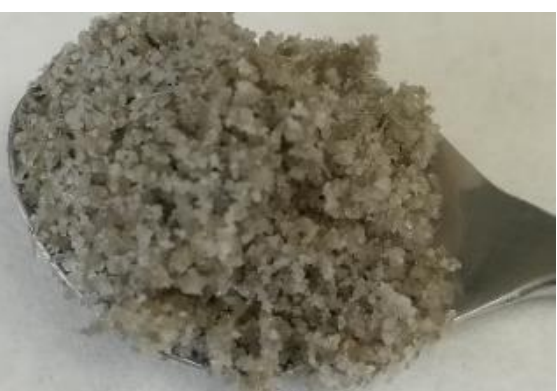

(c)

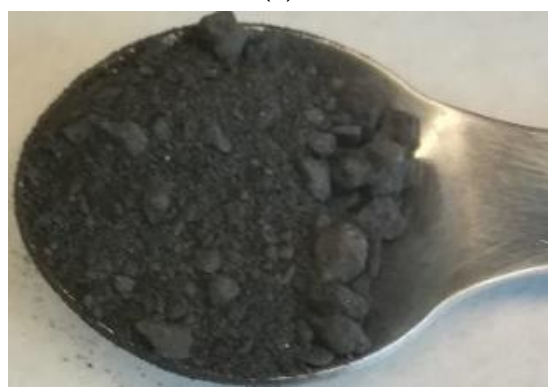

(f)

Figure 1. Supplementary cementitious materials used in this research. (a) bauxite, (b) chamotte, (c) ground granulated blast furnace slag, (d) iron silicate, (e) silica fume, and (f) steel slag.

Table 3. Chemical composition in wt \% and physical properties of SCMs. Data provided by the suppliers.

\begin{tabular}{|c|c|c|c|c|c|c|}
\hline Product & Bauxite & Chamotte & $\begin{array}{l}\text { Ground Granulated } \\
\text { Blast Furnace Slag }\end{array}$ & Iron Silicate & Silica Fume & Steel Slag \\
\hline $\mathrm{Al}_{2} \mathrm{O}_{3}$ & 89.94 & 40.70 & $9-13$ & $6-12$ & 0.15 & 13.50 \\
\hline $\mathrm{SiO}_{2}$ & 5.36 & 55.24 & $34-38$ & $22-30$ & 97 & 19.10 \\
\hline $\mathrm{Fe}_{2} \mathrm{O}_{3}$ & 1.14 & 0.32 & - & $25-35$ & 0.03 & 27.00 \\
\hline $\mathrm{TiO}_{2}$ & 3.02 & 1.09 & $<1$ & - & - & - \\
\hline $\mathrm{CaO}$ & 0.02 & $<0.10$ & $40-44$ & $5-8$ & 0.20 & 27.90 \\
\hline $\mathrm{MgO}$ & 0.02 & $<0.10$ & $6-9$ & - & 0.30 & 2.50 \\
\hline $\mathrm{Na}_{2} \mathrm{O}$ & 0.02 & 0.02 & - & - & 0.05 & - \\
\hline $\mathrm{K}_{2} \mathrm{O}$ & 0.03 & 1.47 & - & - & 0.80 & - \\
\hline $\mathrm{CuO}$ & - & - & - & $0.3-0.9$ & - & - \\
\hline $\mathrm{ZnO}$ & - & - & - & $5-9$ & - & - \\
\hline $\mathrm{Cr}_{2} \mathrm{O}_{2}$ & - & - & - & - & - & 2.50 \\
\hline $\mathrm{MnO}$ & - & - & - & - & - & 5.4 \\
\hline $\begin{array}{l}\text { apparent density } \\
\left(\mathrm{g} / \mathrm{cm}^{3}\right)\end{array}$ & 3.15 & 2.44 & 1.1 & 3.3 & 2.25 & 3.57 \\
\hline $\begin{array}{l}\text { apparent porosity } \\
(\%)\end{array}$ & 12 & 6 & - & - & - & - \\
\hline
\end{tabular}

Ground-granulated blast-furnace slag (GGBS or GGBFS) is a dried and ground fine powder. It comes from a blast furnace as a by-product of steelmaking and it is obtained by quenching molten iron slag in water or steam. $\mathrm{CaO}$ is the main component of GGBS, acting as a retardant during the concrete hardening process, resulting in lower heat of hydration and lower temperature rises. The company EDERSA-Masaveu Industria (Spain) provided this material. Silica fume is a by-product generated during the production of silicon metal or ferrosilicon alloys. Mainly composed of $\mathrm{SiO}_{2}$ and hence having a high pozzolanicity, this product was provided by Mapei (Italy). Iron silicate comes from copper melting process converting into a powder material with a high content of iron and silicon dioxide. Abrasivos Mendiola, S.L. (Spain) provided this material for the present research. Steel slag (SS) is a by-product of steelmaking and was provided by Promsa-Megasa (Spain); 
it is produced during the separation of the molten steel from impurities in steelmaking furnaces. The slag is a complex solution of silicates [12].

On the other hand, fibers are considered a group of filaments of a material, which are created to be added in a matrix material to increase the characteristics and the properties of those. Figure 2 shows the aspect of the several fibers used in this study, and their characteristics are shown in Table 4. Since tire fibers (TF-TR and MF-TR) and metal fiber MF-FP do not have a datasheet from the company, they are not presented in the table.

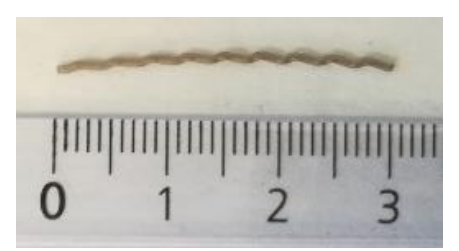

(a)

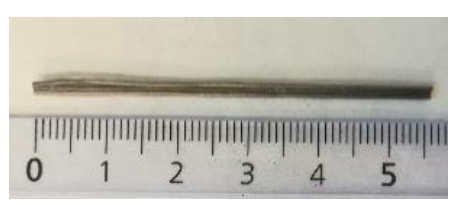

(e)

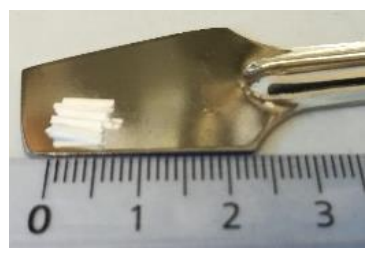

(i)

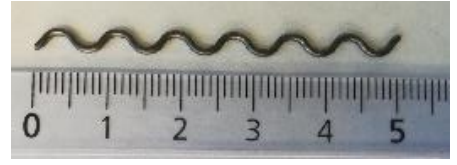

(m)

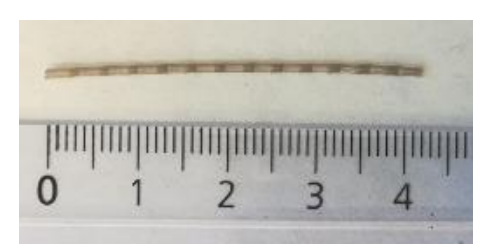

(b)

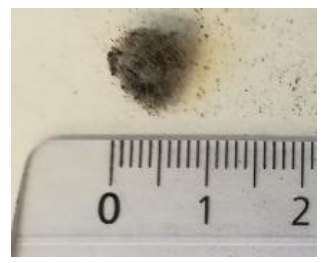

(f)

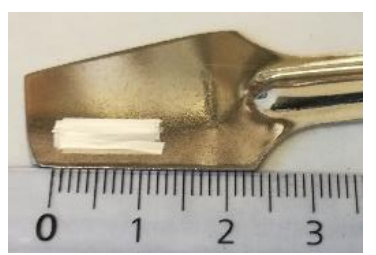

(j)

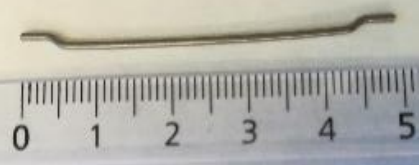

(n)

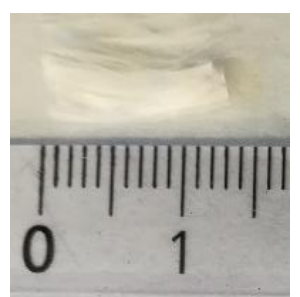

(c)

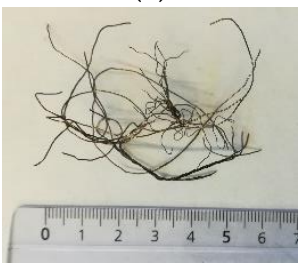

(g)

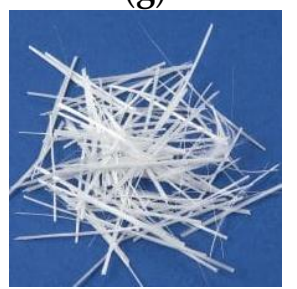

(k)

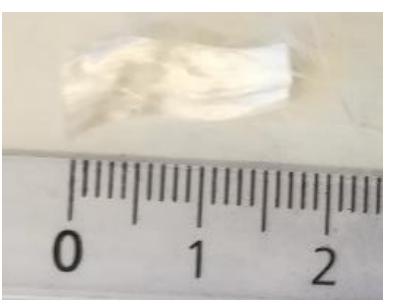

(d)

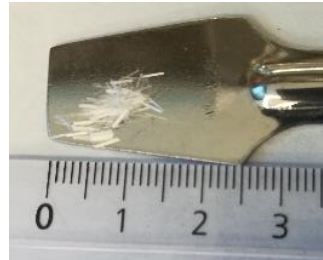

(h)

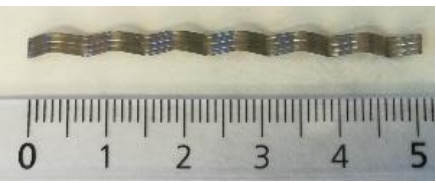

(1)

Figure 2. Fibers used in this research. Polypropylene fibers: (a) ST30, (b) ST42, (c) NS12, (d) NS18, (e) CN54. Pneumatic fibers: (f) TF-TR, (g) MF-TR. Glass fibers: (h) HD3 (i) HD6 (j) HD12 (k) HP. Metal fibers: (1) RW50+, (m) RW50, (n) MF-FP.

Table 4. Characteristics of fibers considered in this study as given by the technical datasheet

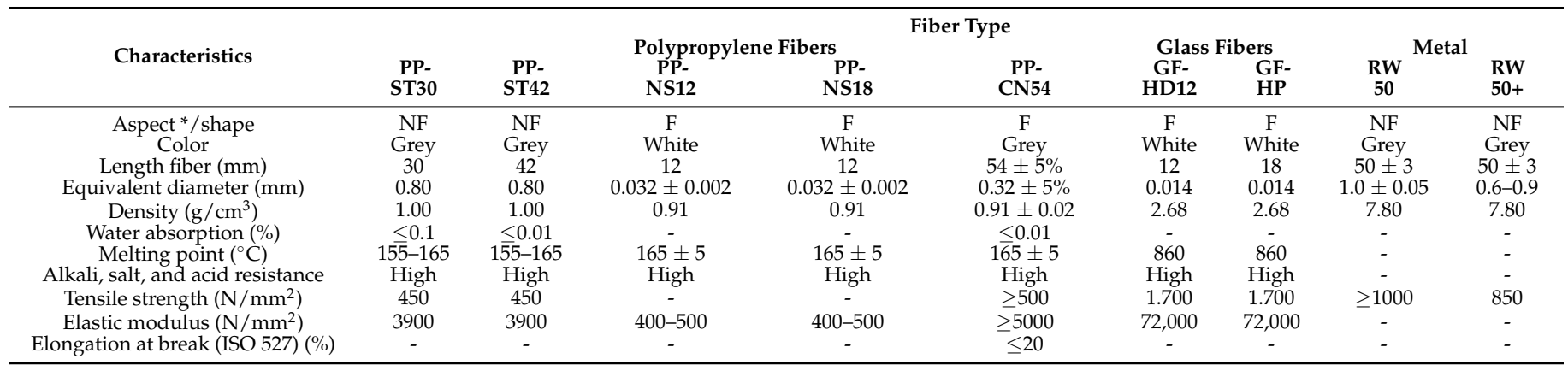

${ }^{*}$ Aspect: Non-filamentous (NF), filamentous (F). 
Among the six types of polymeric fibers, at first sight, they have a difference in their length, color, and shape. ST-30 and ST-42 present waves along the fiber, while NS12, NS18, and PP-CN54 are smoothly straight. Unlike the other fibers NS12, NS18, and PP-CN54 fibers are multifilament fibers, being NS12 and NS18 with higher multifilament proportion. Within the polymeric group of fibers, a tire rubber fiber from pneumatics waste (TF-TR) is found. It has a different aspect compared with the previous commented fibers, with an undefined thin shape grouping all together. These six types of fibers were provided by Mapei (Italy).

Besides polymeric fibers, four glass fibers are analyzed. All of them are multifilament fibers from $3 \mathrm{~mm}$ to $18 \mathrm{~mm}$ length. GF-HD3, GF-HD6, and GF-HD12 were initially selected to be characterized, but the small length limited the tensile tests. This constraint reduced the number of glass fibers, being only possible to consider GF-HP. All glass fibers were provided by Comercial Coll Vila (Spain).

The last fibers selected for this study are four types of metal fibers. RW50+ and RW50 fibers are wavy, with some difference in shape, being RW50+ multifilament. MF-FP fibers are quite different from the other metal fibers, being straight in the center with a hooked finish on both sides of the fiber. The fourth metal fiber comes from the metal wire from the pneumatic tire waste. As it can be seen in Figure 2, they have irregular shapes and length. Thus, this is something to take into account if it is desired to use them in concrete. MF-TR were provided by Gestión Medioambiental de Neumáticos S.L. (Spain) and MF-FP fibers from MAC (Perugia, Italy).

\subsection{Analytical Methods}

\subsubsection{Supplementary Cementitious Materials}

To study the morphology and microstructure of SCM particles, Figure 3 shows the sample preparation procedure. A small portion of each SCM was embedded in epoxy resin, and further cured at room temperature. Once the samples were hardened, they were smoothed with roughing paper and polished with a polishing machine and diamond paste until the surface was as flat and shiny to be tested on the metallographic bench camera of the microscope. The optical microscopy analysis was carried out through the microscope "Axiovert 100 A, Zeiss" and the software AxioVision 4.6 viewer from Carl Zeiss was used for the image visualization.

X-ray diffraction analysis (XRD) was carried out according to European standard EN12698-2 [39,40]. The equipment used was a PANalytical X'Pert PRO MPD Alpha1 powder diffractometer in Bragg-Brentano $\theta / 2 \theta$ geometry of $240 \mathrm{~mm}$ of radius: $\mathrm{Cu} \mathrm{K} \alpha 1$ radiation $(\lambda=1.5406 \AA)$, with a working power of $45 \mathrm{kV}-40 \mathrm{~mA}$.

To study the potential of the SCMs a key parameter is the pozzolanic reaction between the SCMs and the calcium hydroxide $\left(\mathrm{Ca}(\mathrm{OH})_{2}\right)$. This was studied by preparing a mixture of each SCMs in a solution of $\mathrm{Ca}(\mathrm{OH})_{2}$ and water, simulating the SCM and Portland cement blend with the ratio: $100 \mathrm{~g} \mathrm{Ca}(\mathrm{OH})_{2}: 25 \mathrm{~g} \mathrm{SCM}: 187.5 \mathrm{~g} \mathrm{H}_{2} \mathrm{O}$. After the mixing process, the resulting mixture of each SCM was divided in four pots, as shown in Figure 4 . One pot exposed to the air and another one closed for two days before the analysis. Two more samples without SCM were prepared only with $\mathrm{Ca}(\mathrm{OH})_{2}$ and $\mathrm{H}_{2} \mathrm{O}$, to use them as references. 


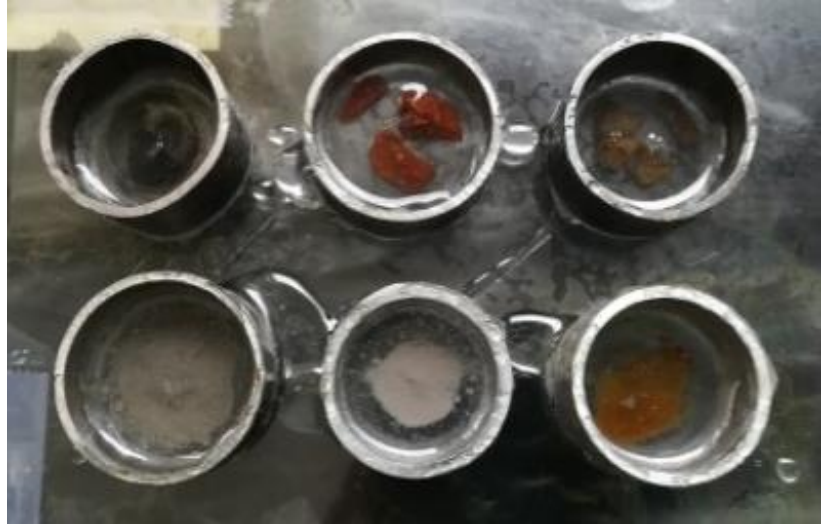

(a)

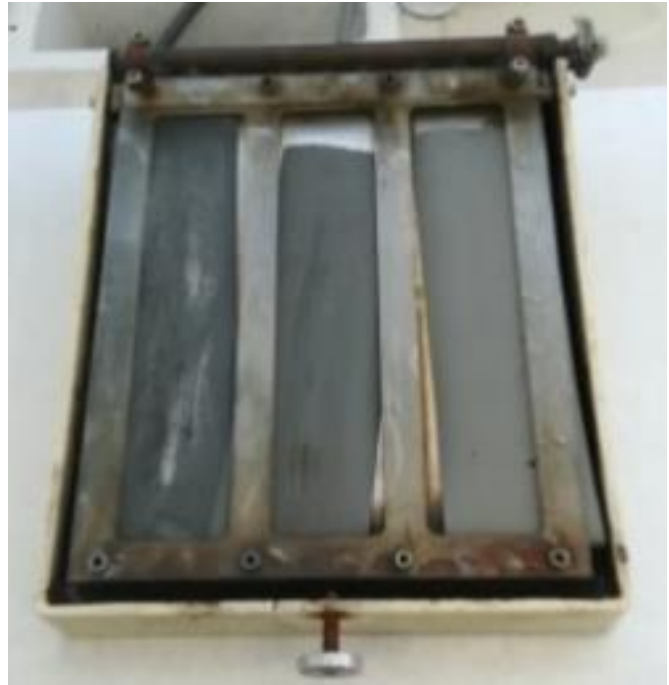

(c)

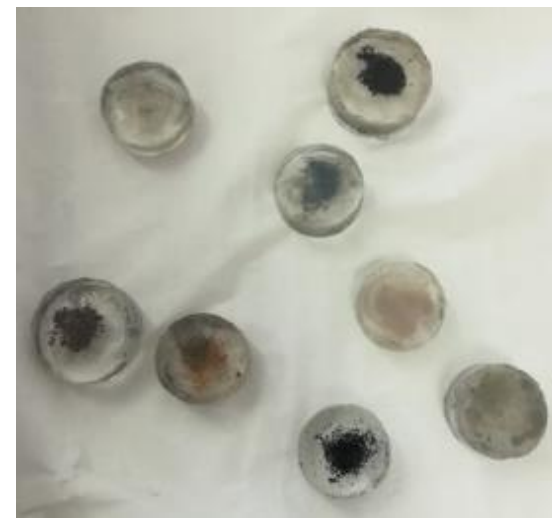

(b)

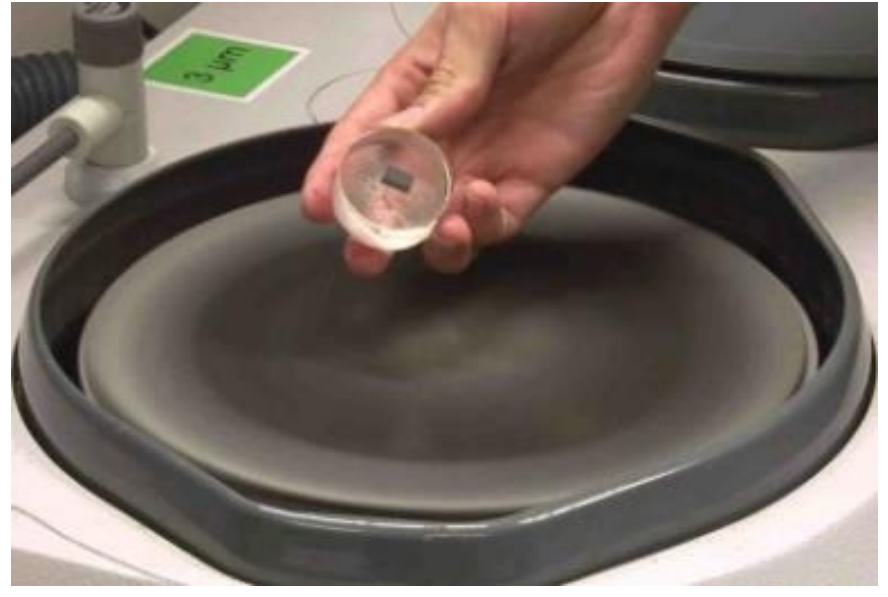

(d)

Figure 3. Optical microscopy sample preparation. (a,b) Preparation samples for the metallographic bench, (c) roughing paper, (d) polishing machine.

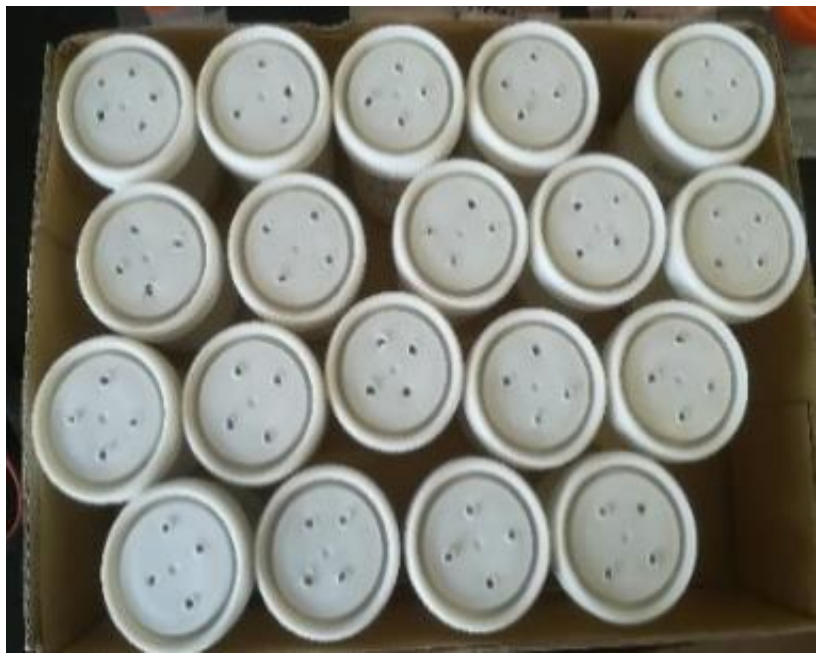

(a)

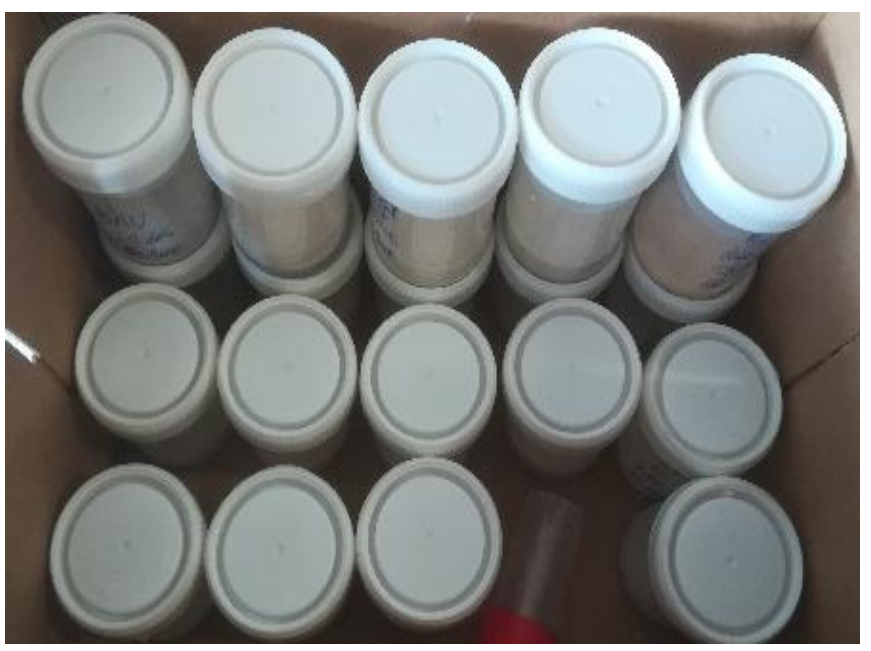

(b)

Figure 4. (a) Samples exposed to air, (b) samples not exposed to air. 
Moreover, it was considered interesting to study if there are differences between samples exposed to the air and others not exposed. Holes were done in the cover of the pot in some sample while the others were fixed with parafilm (Figure 4).

These blends were analyzed in the Fourier transform infrared spectroscopy (FT-IR) after 14 and 28 days, to analyze the reactivity of the $\mathrm{SiO}_{2}$ of each SCM with the $\mathrm{Ca}(\mathrm{OH})_{2}$. (FTIR) was performed using a Fourier Perkin Elmer frontier spectrum equipment and selecting the attenuated total reflectance sampling (ATR) technique. The sample in powder format was used and placed in the equipment crystal for the spectrum analysis. In the software analysis a wavelength scanning was selected between $4000 \mathrm{~cm}^{-1}$ and $450 \mathrm{~cm}^{-1}$. When the diagrams were generated to analyze if the silicon of the SCM reacts with the calcium of the $\mathrm{Ca}(\mathrm{OH})_{2}$ and produces tobermorite, which means that $\mathrm{CSH}$ (calcium silicate hydrate) is formed [41].

\subsubsection{Fibers}

First, fiber samples were weighted using a scale model Mettler Toledo AG135, and measured the length with a caliper. Also, the optical microscopy analysis used the optical microscope "Axiovert $100 \mathrm{~A}$, zeiss" using a binocular loupe to measure the diameter of the fiber, to determine if the fiber is solid or hollow, and other morphological characteristics.

Apart from the characterization of fibers without any treatment (reference fiber), this research pretended to go one-step further and study fibers under service conditions being in contact with concrete. A NaOH solution with a $\mathrm{pH}$ of 13.5 was prepared to simulate $\mathrm{pH}$ conditions of fresh concrete to submerge the fibers. Six replicates for each kind of fiber were placed inside tubes for one month and six more for three months. These six repetitions of fibers samples were used for the tensile strength tests.

The tensile test was carried out to fibers without any treatment, fibers exposed to $\mathrm{pH}$ for one month, and another group of fibers tested after three months inside the basic solution. The tensile test was performed following the literature standards ASTM (D638) and UNE 40 -248-75 [42,43] with a Zwick/Roell zmart pro equipment (Figure 5). The strain rate for this test was $5 \mathrm{~mm} / \mathrm{min}$ for the PP fibers and $50 \mathrm{~mm} / \mathrm{min}$ for the metal fibers. Moreover, two types of load cells were used: $200 \mathrm{~N}$ and $10 \mathrm{kN}$, depending on the sample.

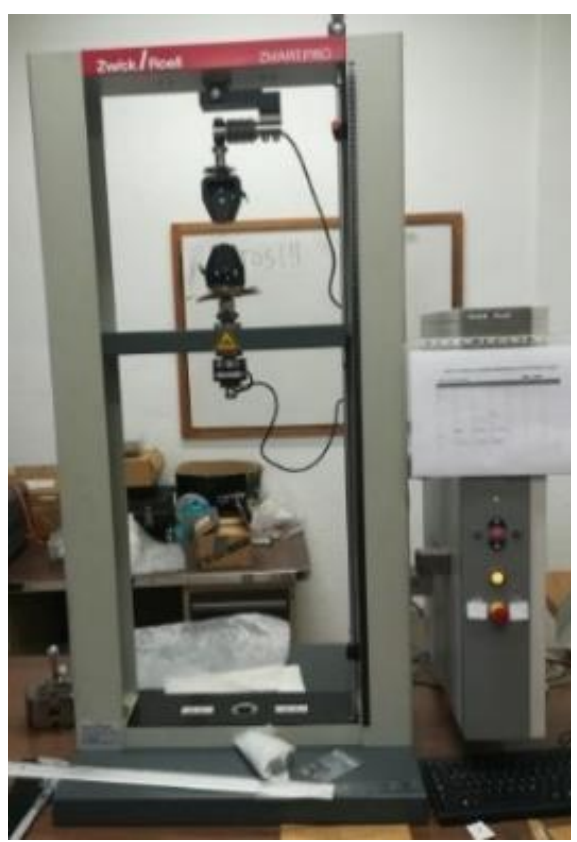

(a)

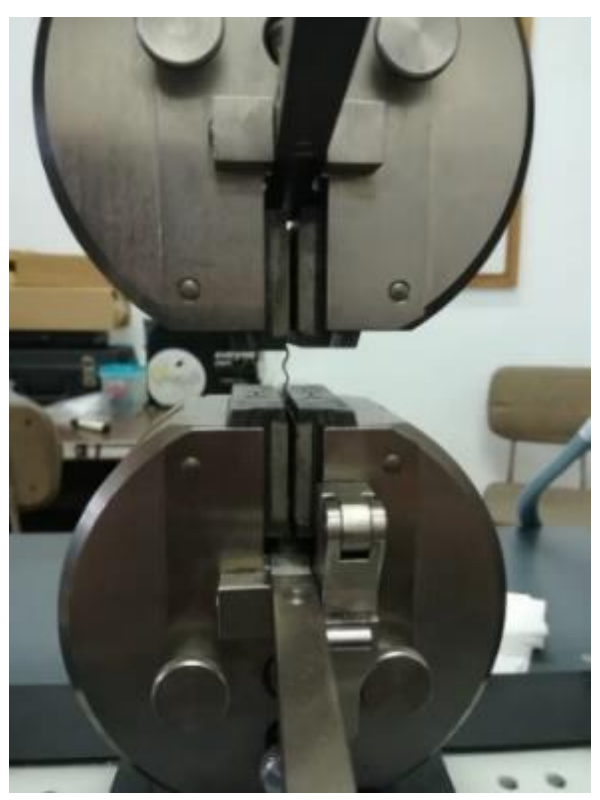

(b)

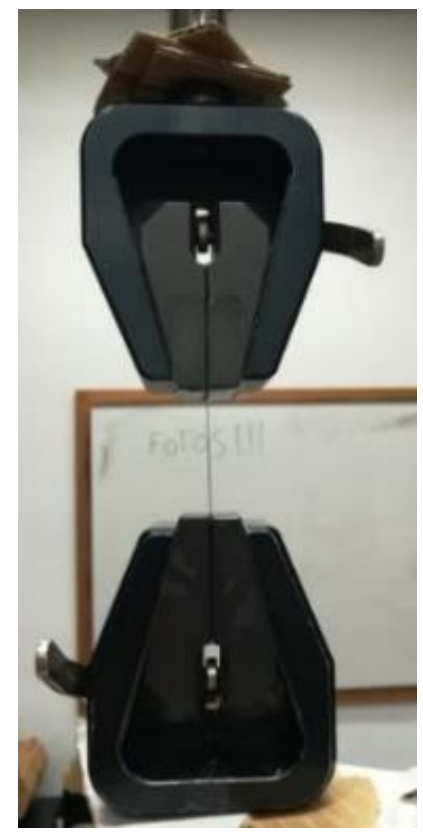

(c)

Figure 5. (a) Tensile strength machine, (b) load cell $200 \mathrm{~N}$, and (c) load cell $10 \mathrm{kN}$. 


\section{Results}

3.1. SCM

In Figure 6 are shown the SCM images obtained with optical microscope. Bauxite, chamotte, ground granulated blast furnace slag, iron silicate, and steel slag are composed by irregular polyhedral shape particles with sharp corners and edges, whether regular circular shape particles compose silica fume. Regarding the surface, chamotte, silica fume, GGBFS, and iron silicate present massive particles that have a smooth surface, while bauxite and steel slag have a rough surface.

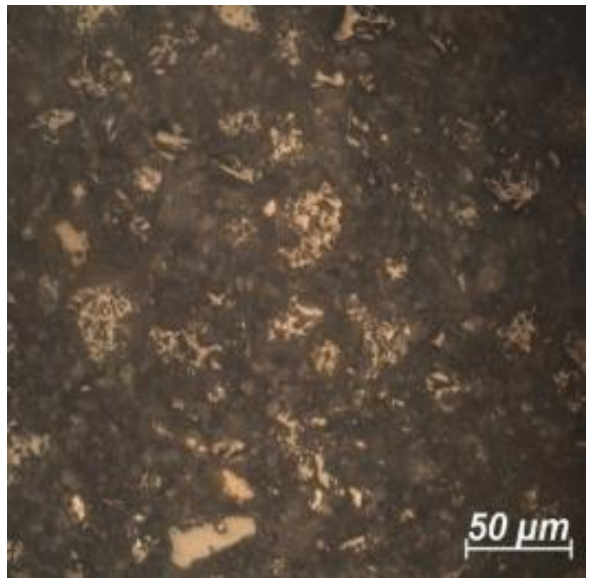

(a)

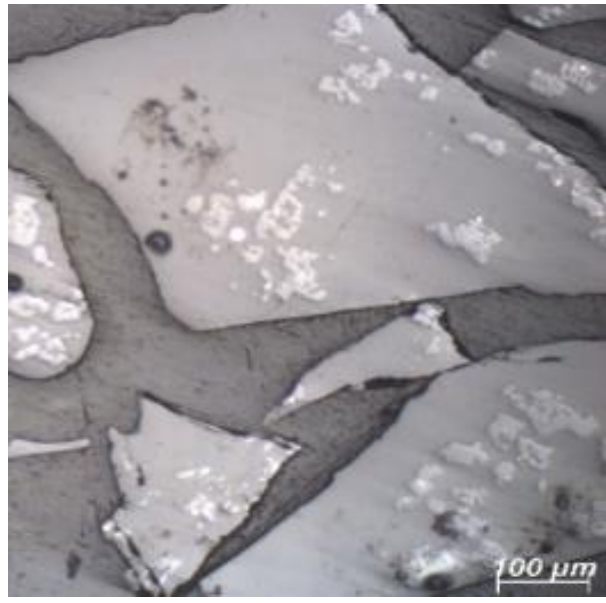

(d)

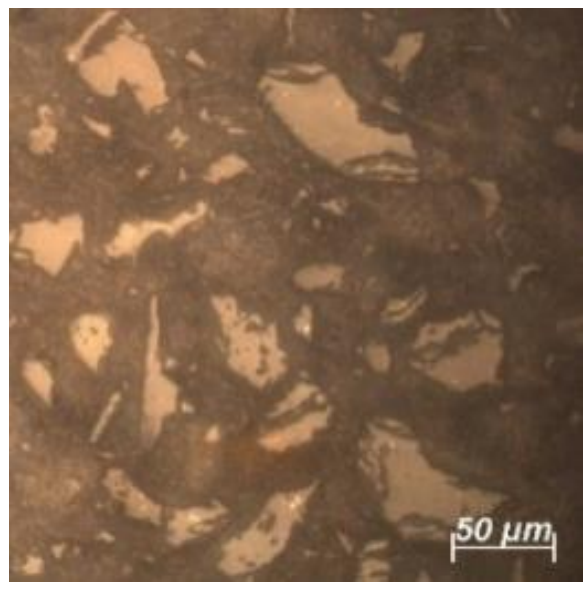

(b)

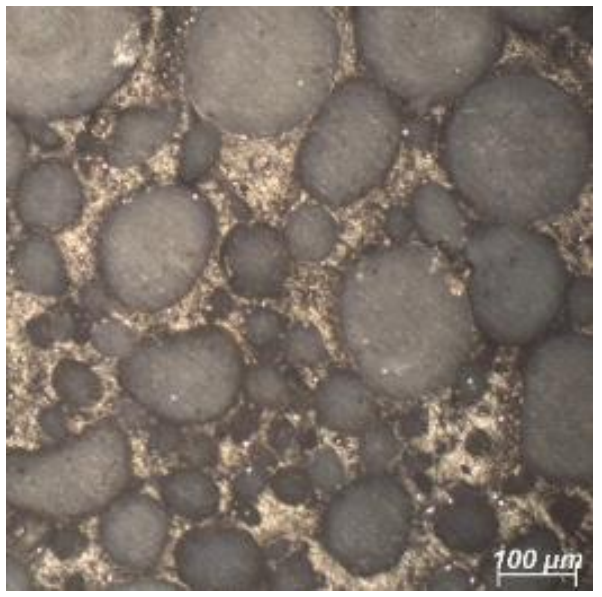

(e)

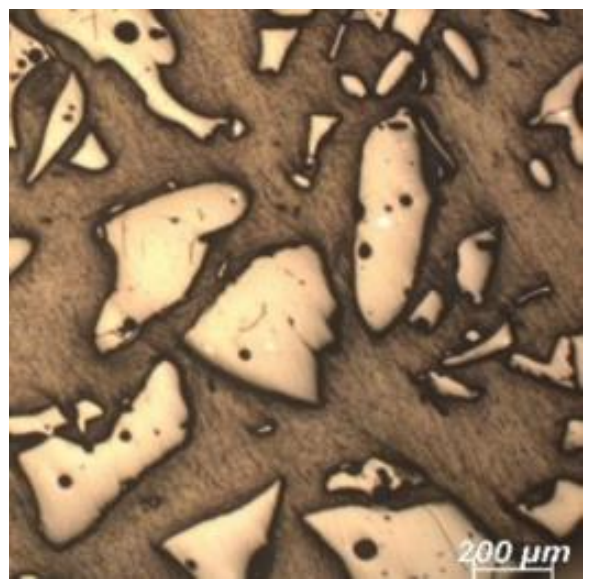

(c)

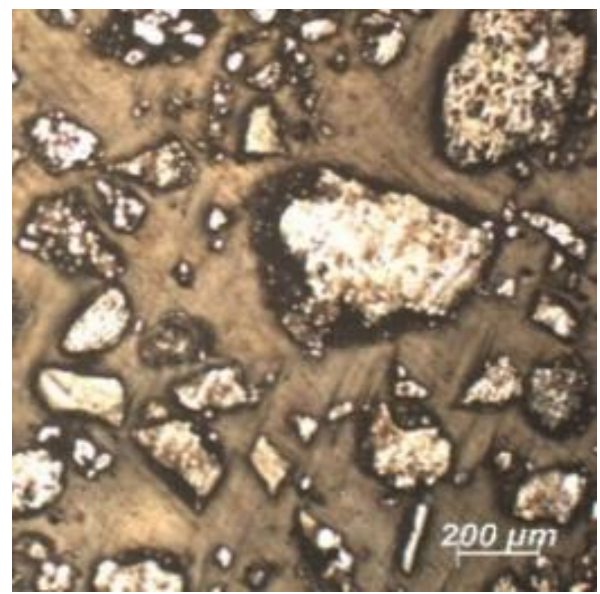

(f)

Figure 6. Metallographic results. (a) bauxite, (b) chamotte, (c) ground granulated blast furnace slag, (d) iron silicate, (e) silica fume, (f) steel slag.

From a qualitative perspective, Table 5 shows that the particle size observed through the metallographic bench. Bauxite and chamotte have the smallest particle size from 11 to $55 \mu \mathrm{m}$. The other SCM analyzed have a higher particle size and a wide dispersion in-between particle size. 
Table 5. Particle size of SCM

\begin{tabular}{cc}
\hline SCM & Particle Size \\
\hline Bauxite & 11 and $31 \mu \mathrm{m}$ \\
Chamotte & 17 and $55 \mu \mathrm{m}$ \\
Ground granulated blast furnace slag & 50 and $420 \mu \mathrm{m}$ \\
Iron silicate & 75 and $332 \mu \mathrm{m}$ \\
Silica fume & 39 and $287 \mu \mathrm{m}$ \\
Steel slag & 80 and $390 \mu \mathrm{m}$ \\
\hline
\end{tabular}

In XRD diagrams presented in Figure 7, Bauxite and Chamotte samples show a diffractogram of a crystalline sample formed by a mixture of phases. In Bauxite sample (a) the main crystalline phases are $\mathrm{Al}_{2} \mathrm{O}_{3}$ (aluminum oxide) followed by $\mathrm{Al}_{4} \mathrm{SiO}_{8}$ (Mullite), while in Chamotte sample $(\mathbf{b})$ the main phases are $\mathrm{Al}_{6} \mathrm{O}_{13} \mathrm{Si}_{2}$ (mullite, aluminum silicate) and $\mathrm{SiO}_{2}$ (quartz). Otherwise, Steel slag diffractogram (c) shows both: peaks corresponding to crystalline phases and amorphous phases seen by the non-flat baseline that goes up at higher angles and is typical of amorphous phases with high Fe content. The peaks corresponding to crystalline phases were identified as $\mathrm{Al}_{2} \mathrm{Ca}_{2} \mathrm{O}_{7} \mathrm{Si}$ (Gehlenite, calcium aluminum silicate $)$ and manganese magnesium oxide $\left((\mathrm{MgO})_{0.59}(\mathrm{MnO})_{0.41}\right)$ as major phases, and $\mathrm{Fe}_{3} \mathrm{O}_{4}$ (magnetite) and $\mathrm{Ca}_{2} \mathrm{O}_{4} \mathrm{Si}$ (calcium silicate) as minor phases. On the other side, the iron silicate sample (d) is mainly amorphous, while few low-intensity crystalline peaks are identified, and these correspond to $\mathrm{Fe}_{2} \mathrm{SiO}_{4}$ (iron silicate). As in sample (c), the high Fe content of the sample produces a baseline that goes up at higher angles.

Nevertheless, some crystalline $\mathrm{SiO}_{2}$ (Silicon Oxide) phase peaks are identified, being silica fume diffractogram (e) in general amorphous. On the other hand, ground granulated blast furnace slag is amorphous and does not present peaks of crystalline phases.

FT-IR was used to follow the pozzolanic reaction. From this test, were checked the decrease in the intensity of the Si-O peaks and the appearance of new phase peaks of tobermorite (CSH).

As a general trend observed in Figure 8, there is no difference between the mixture samples of $\mathrm{SCM}$ and $\mathrm{Ca}(\mathrm{OH})_{2}$ which were exposed to an air environment and the mixtures without being exposed to an air environment. These results were not expected since $\mathrm{CO}_{2}$ should have reacted with the material. For this reason, it is thought that the no air samples were not isolated in a proper way. The ground granulated blast furnace slag was not possible to test.

Bauxite after the pozzolanic test shows at $3500 \mathrm{~cm}^{-1}$, the $\mathrm{OH}$ peak. Moreover, at $805 \mathrm{~cm}^{-1}$ indicates the tobermorite presence after the pozzolanic test, corresponding to $\mathrm{CSH}$ formation. The bauxite reference sample and the mixtures had some differences. In the reference samples bauxite has an important peak in the $400-500 \mathrm{~cm}^{-1}$ caused by bending of the $\mathrm{SiO}_{4}$ tetrahedral units.

Before the pozzolanic test, in silica fume, stands out the $1060 \mathrm{~cm}^{-1}$ peak, which represents $\mathrm{Si}-\mathrm{O}$. After the pozzolanic test, the $\mathrm{OH}$ peak was observed, corresponding to band $3500 \mathrm{~cm}^{-1}$, tobermorite at $1050 \mathrm{~cm}^{-1}$, and calcium carbonate at $1400 \mathrm{~cm}^{-1}$.

Since chamotte, iron silicate, and steel slag are formed by silicates, they showed practically the same FT-IR result. Differences were observed between the reference cementitious materials and the mixture with $\mathrm{Ca}(\mathrm{OH})_{2}$. The FTIR peaks observed were the same as in the four previous commented SCM. One important peak at $805 \mathrm{~cm}^{-1}$, which corresponds to Si-O. After the pozzolanic test, at $3500 \mathrm{~cm}^{-1}$ a OH peak appeared in the FTIRs. Also, it can be seen peaks at $3000-2800 \mathrm{~cm}^{-1}$ in some mixtures, which correspond to $\mathrm{H}_{2} \mathrm{O}$, meaning that the mixture was not dry enough. Like bauxite, the tobermorite peak that ensures the pozzolanic activity was found at $805 \mathrm{~cm}^{-1}$. 


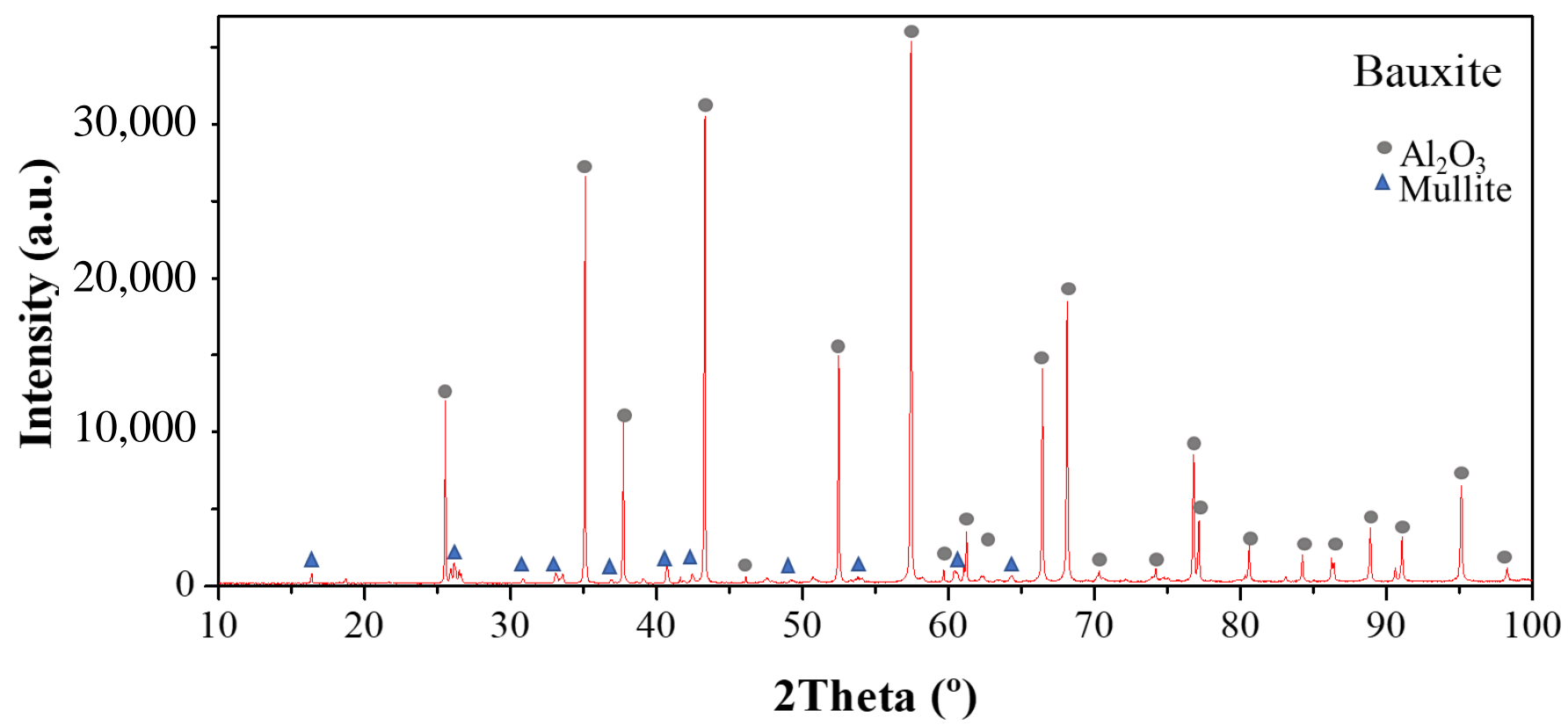

(a)

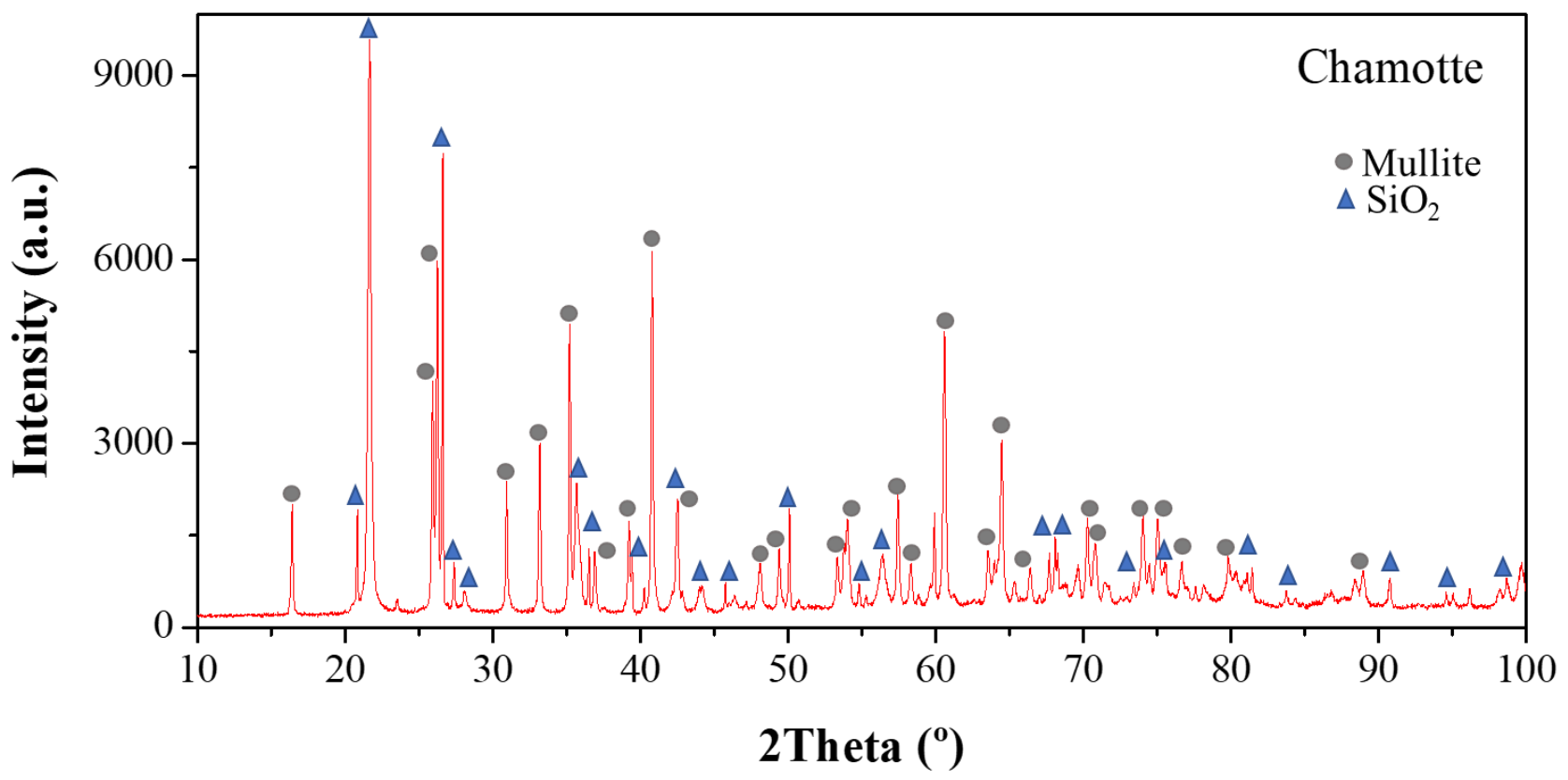

(b)

Figure 7. Cont. 


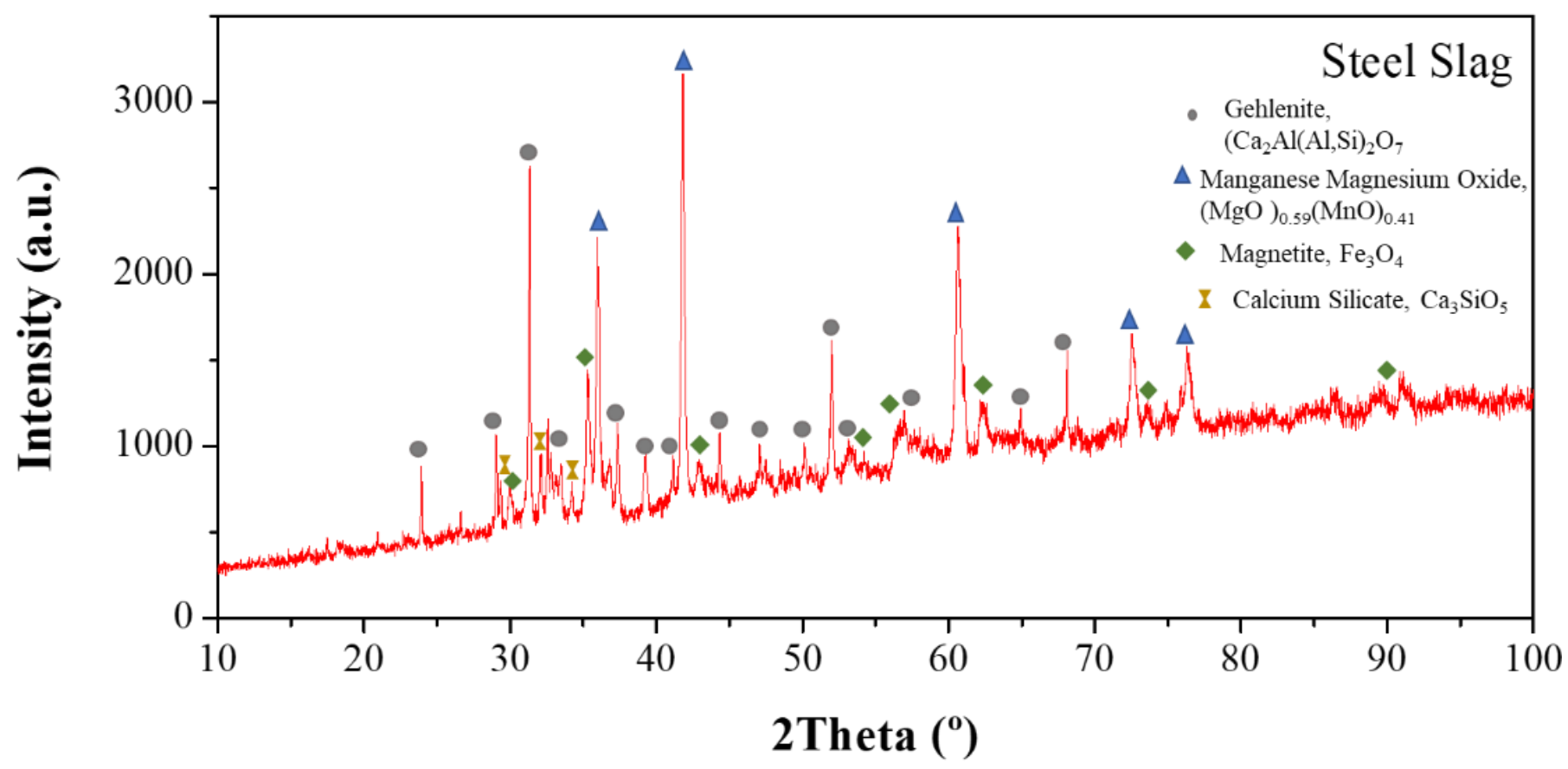

(c)

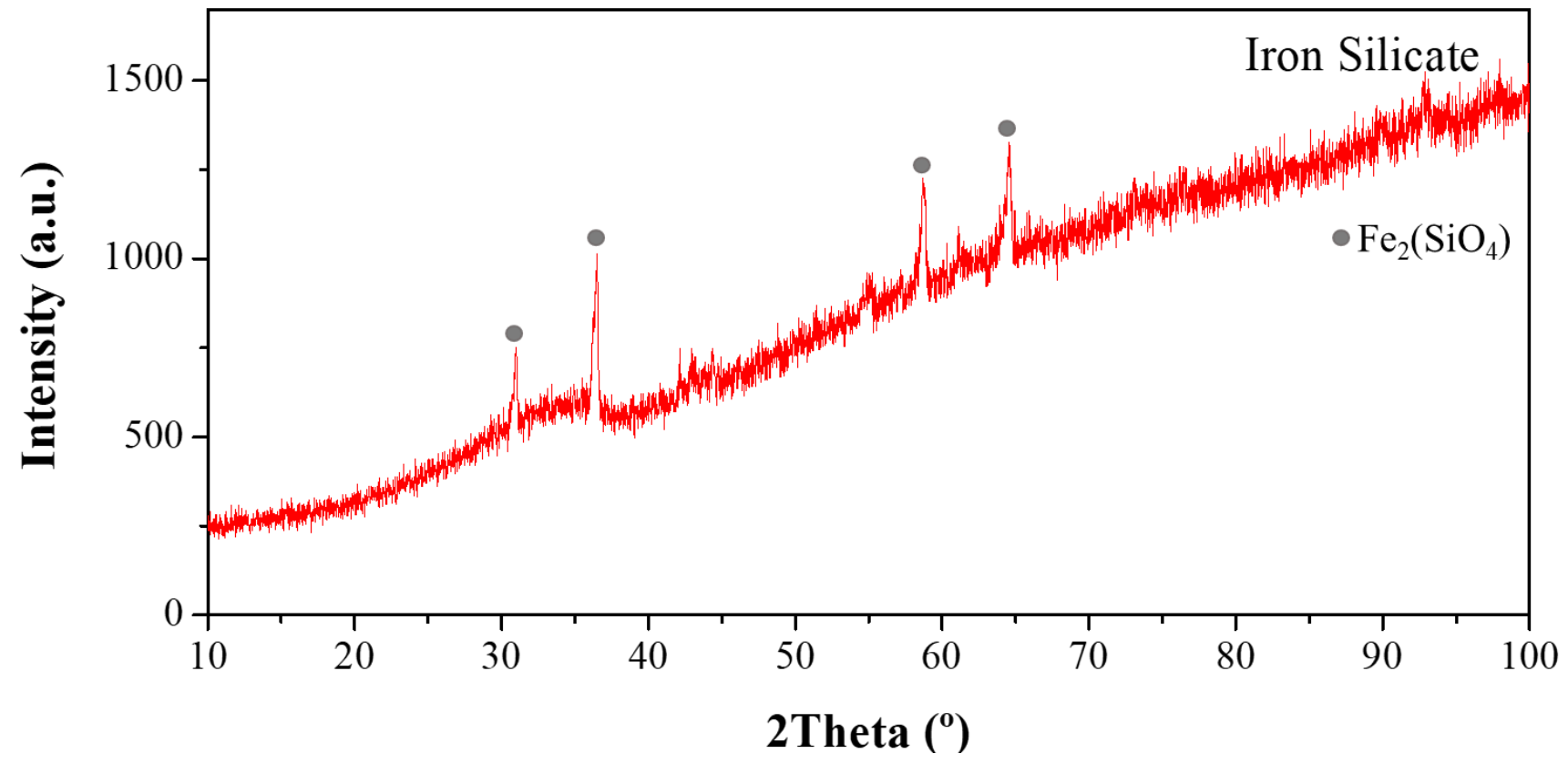

(d)

Figure 7. Cont. 


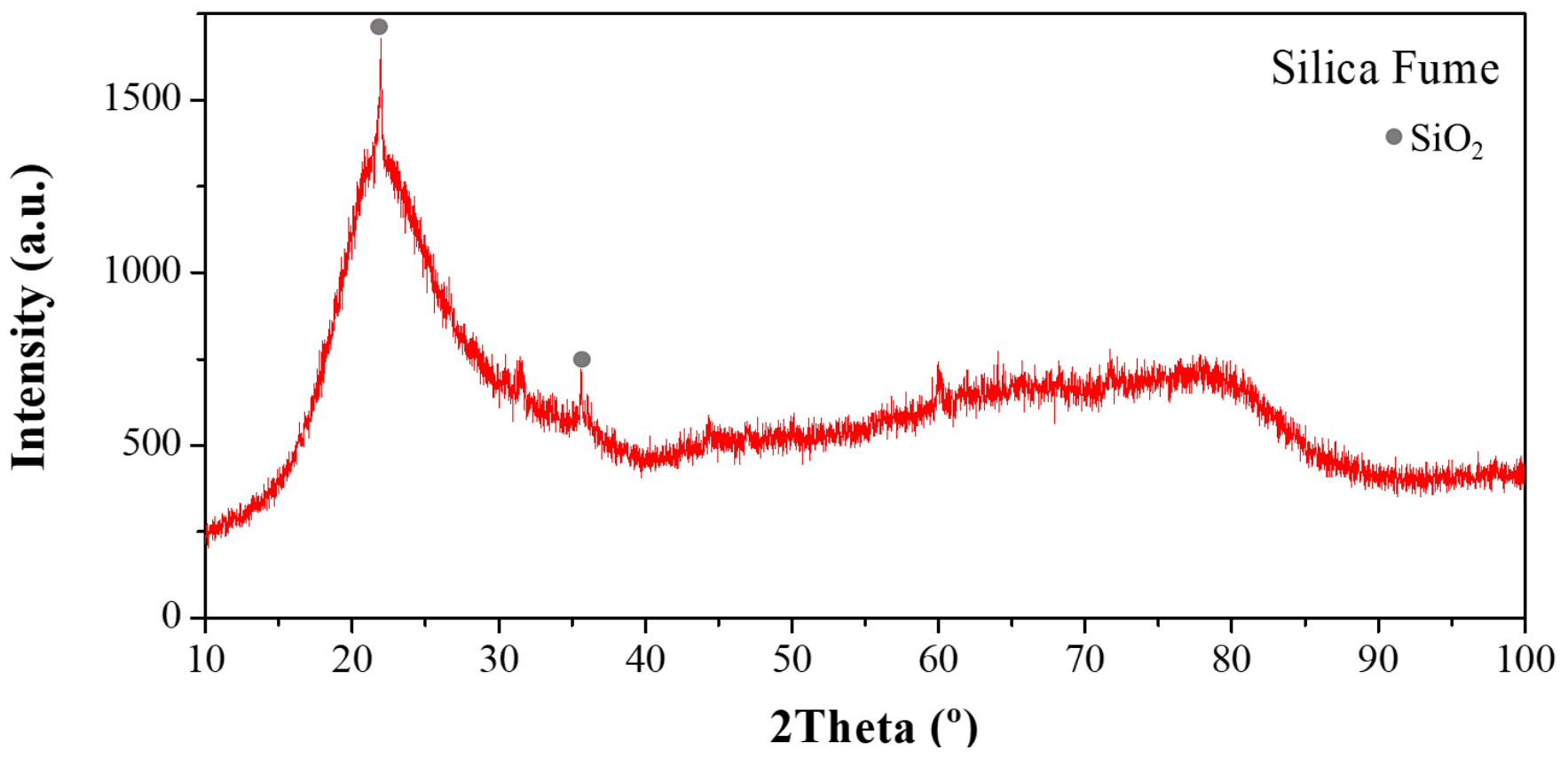

(e)

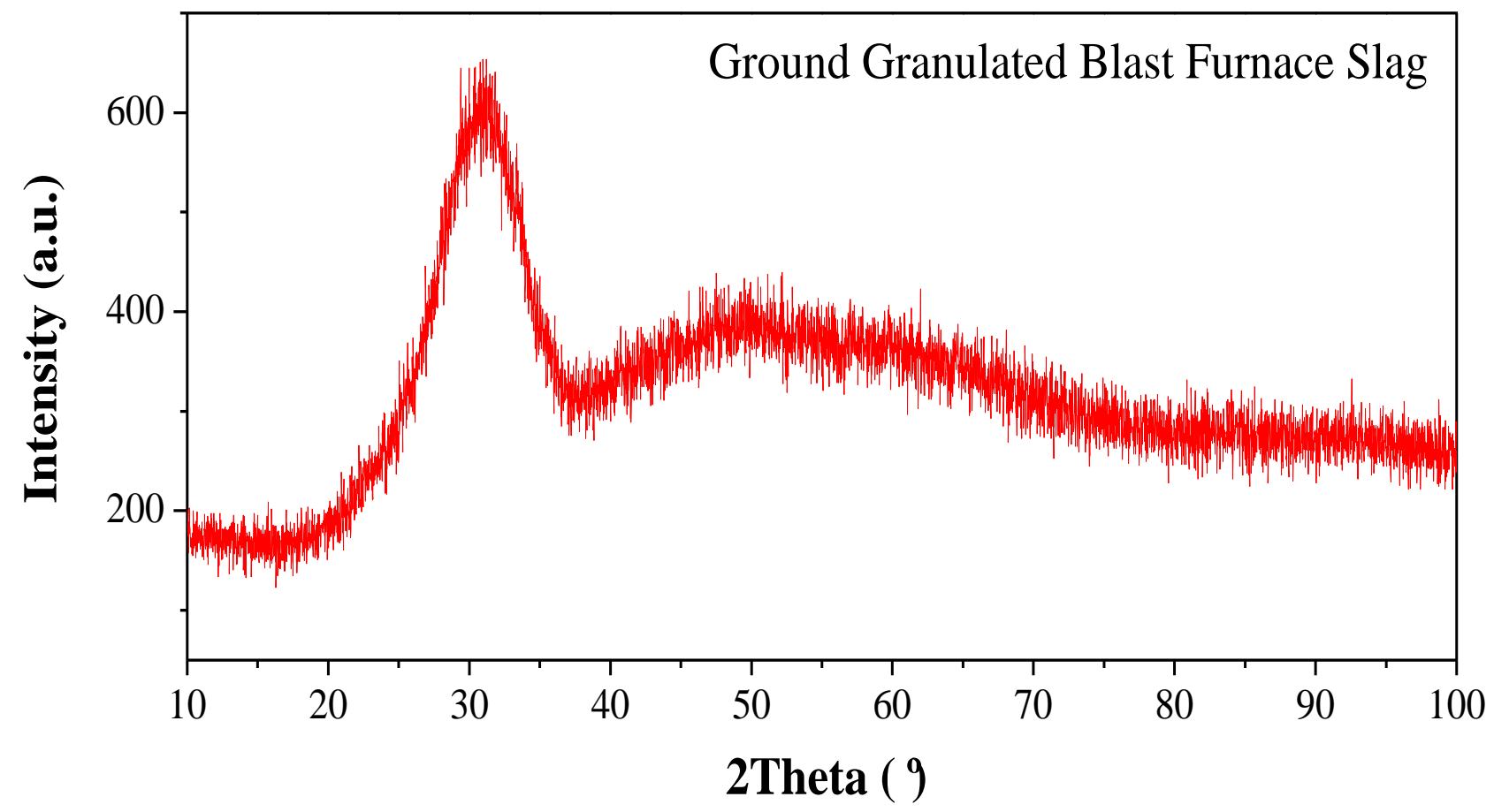

(f)

Figure 7. XRD diagram (a) bauxite, (b) chamotte, (c) ground granulated blast furnace slag, (d) iron silicate, (e) silica fume, (f) steel slag. 
$\mathrm{Ca}(\mathrm{OH})_{2}$ with no addition was tested in order to have a reference to compare with the other spectra. The peak of tobermorite is also seen here but with less intensity as the SCM's increase the formation of $\mathrm{CSH}$, suggesting that in the $\mathrm{Ca}(\mathrm{OH})_{2}$, there are some silicates as minor phases or impurities.

Also, in Table 6 are observed the peak values of the FT-IR results. The six supplementary cementitious materials studied present the common peak when they were mixed with $\mathrm{Ca}(\mathrm{OH})_{2}$, an intense peak at $1400 \mathrm{~cm}^{-1}$ which is from the calcium carbonate.

Table 6. FT-IR peaks of the SCM pozzolanic test

\begin{tabular}{|c|c|c|c|}
\hline SCM & & Band $\left(\mathrm{cm}^{-1}\right)$ & Phases \\
\hline \multirow{5}{*}{ Silica Fume } & \multirow{2}{*}{ Before pozzolanic test } & 1060 & Si-O (stretching) \\
\hline & & 805 & Si-O (bending) \\
\hline & \multirow{3}{*}{ After pozzolanic test } & 3600 & $\mathrm{Ca}(\mathrm{OH})_{2}$ \\
\hline & & 1400 & Calcium carbonate \\
\hline & & 1050 & Tobermorite \\
\hline \multirow{4}{*}{ Bauxite } & \multirow[t]{2}{*}{ Before pozzolanic test } & $400-500$ & $\mathrm{SiO}_{4}$ (bending) \\
\hline & & 3600 & $\mathrm{Ca}(\mathrm{OH})_{2}$ \\
\hline & \multirow[t]{2}{*}{ After pozzolanic test } & 1400 & Calcium carbonate \\
\hline & & 805 & Tobermorite \\
\hline \multirow{4}{*}{$\begin{array}{c}\text { Iron Silicate- } \\
\text { ChamotteSteel } \\
\text { slag }\end{array}$} & \multirow[t]{2}{*}{ Before pozzolanic test } & 805 & Si-O (bending) \\
\hline & & 3600 & $\mathrm{Ca}(\mathrm{OH})_{2}$ \\
\hline & \multirow[t]{2}{*}{ After pozzolanic test } & 3000-2800 & $\mathrm{H}_{2} \mathrm{O}$ \\
\hline & & 1400 & Calcium carbonate \\
\hline
\end{tabular}

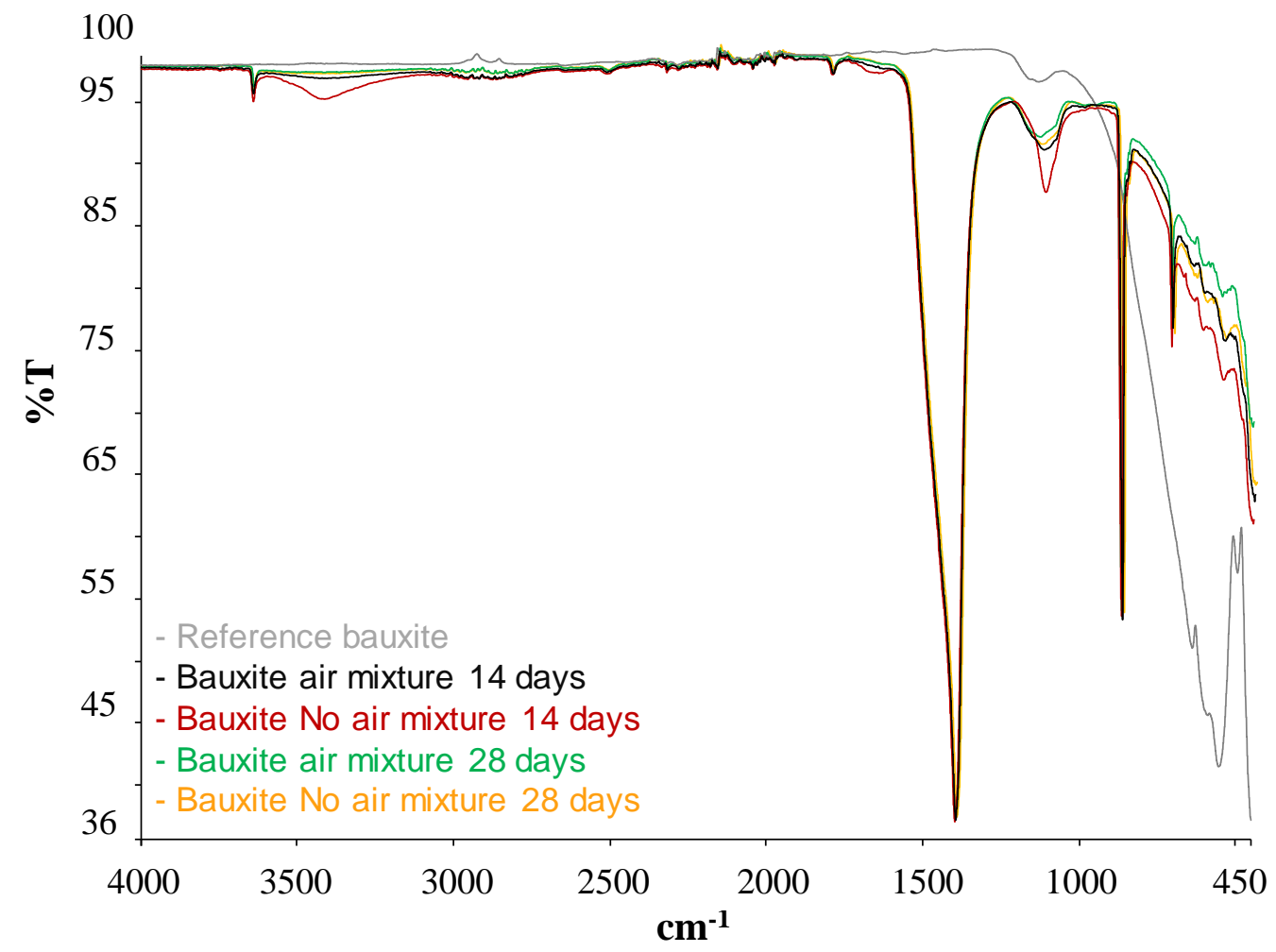

(a)

Figure 8. Cont. 


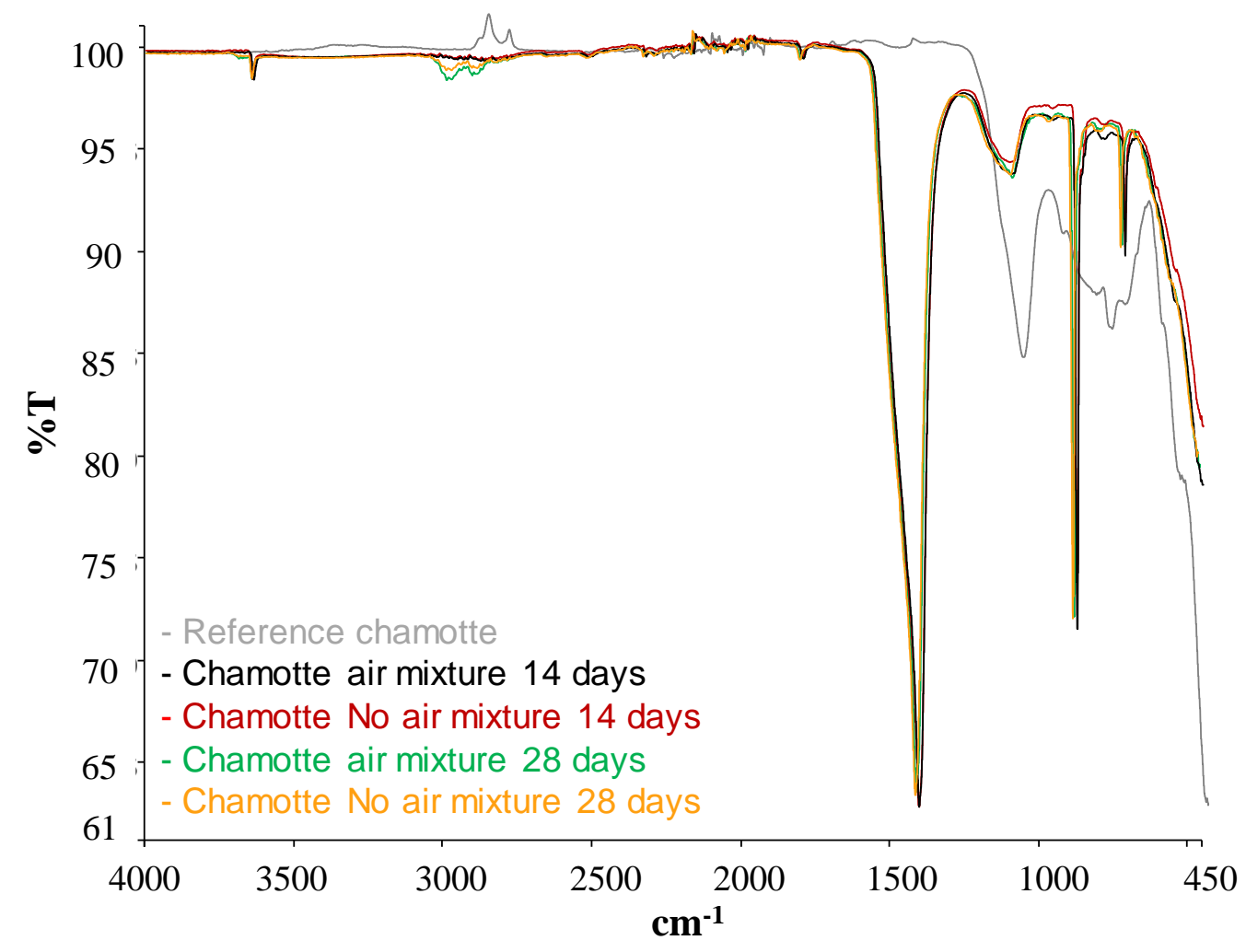

(b)

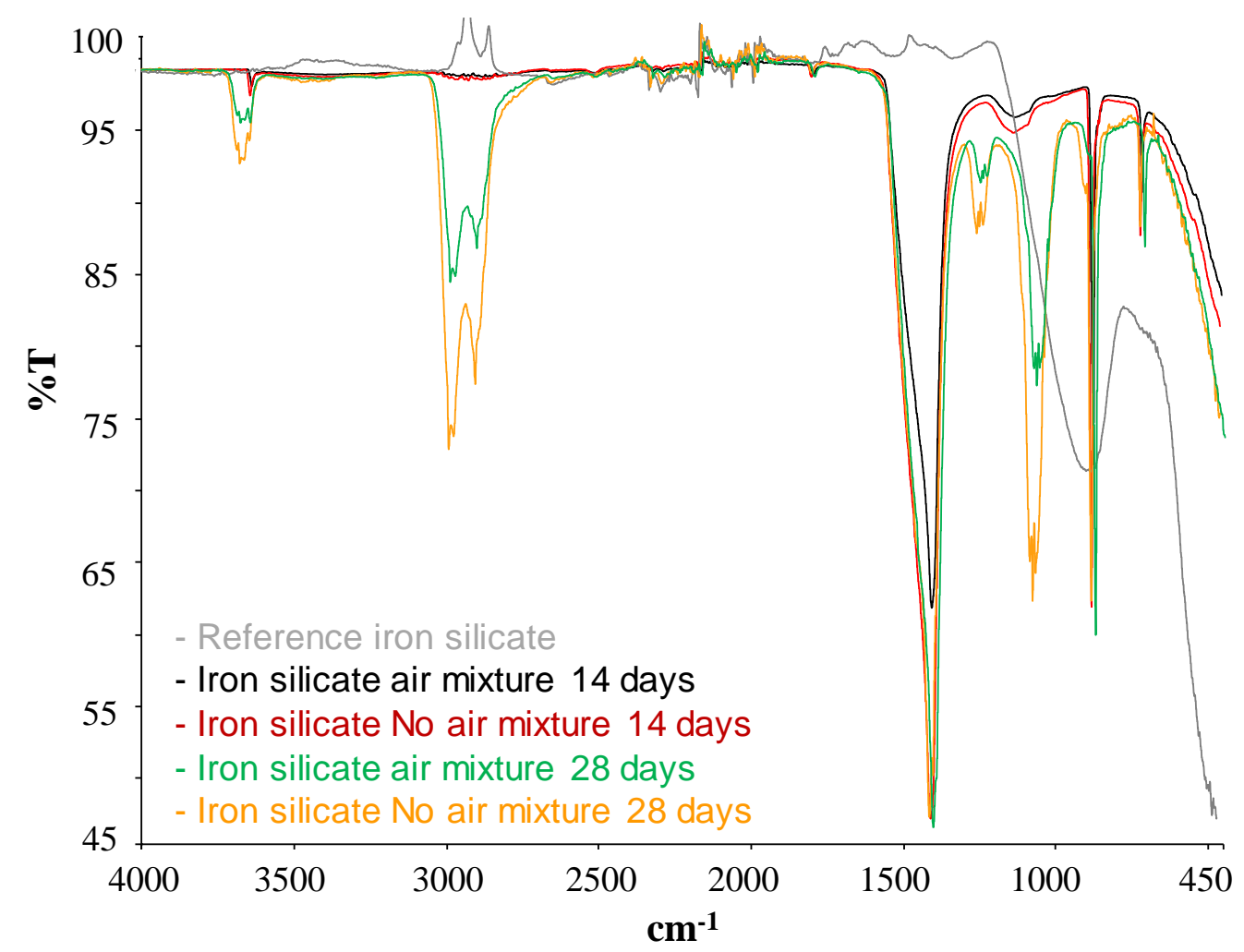

(c)

Figure 8. Cont. 


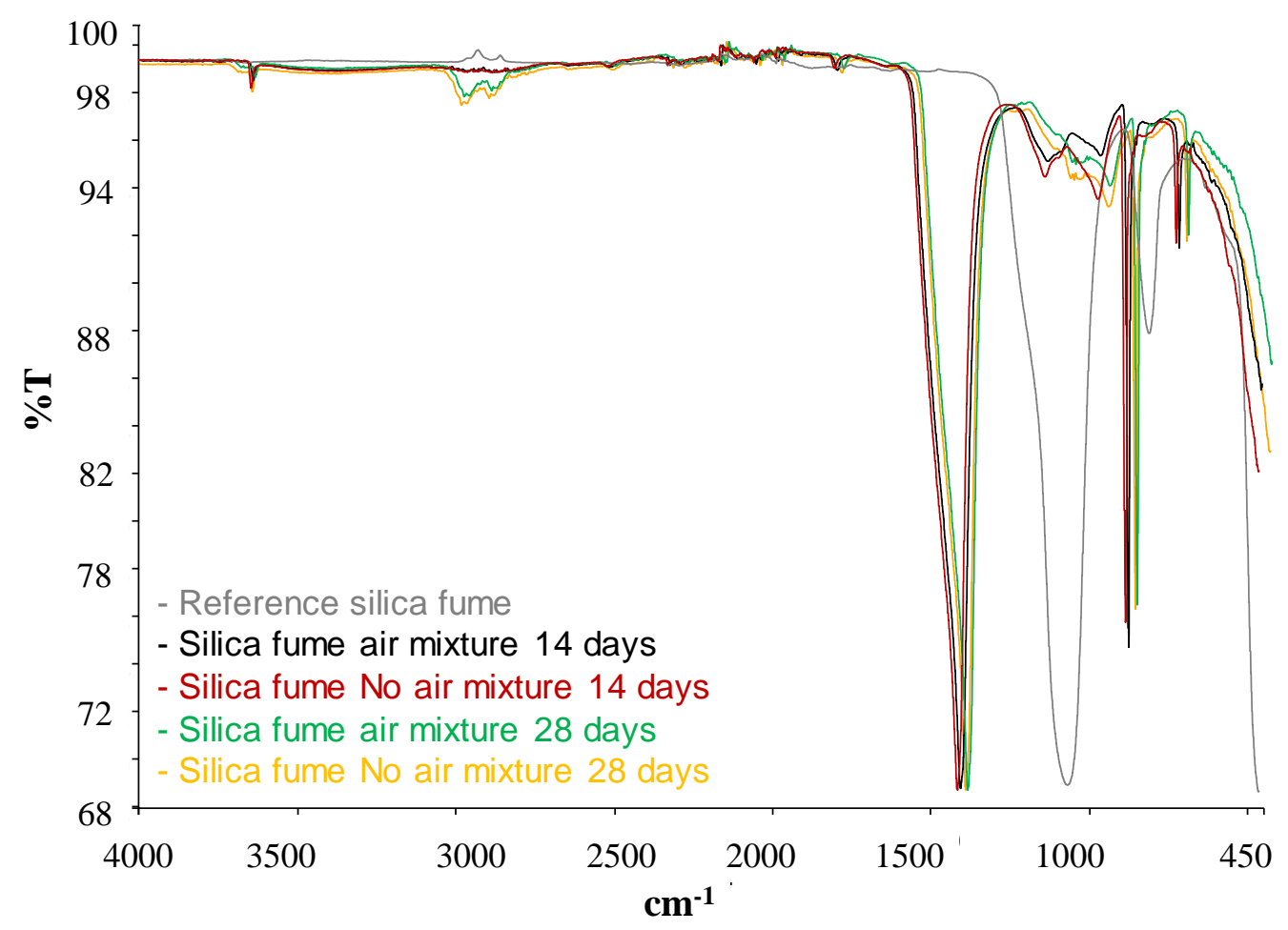

(d)

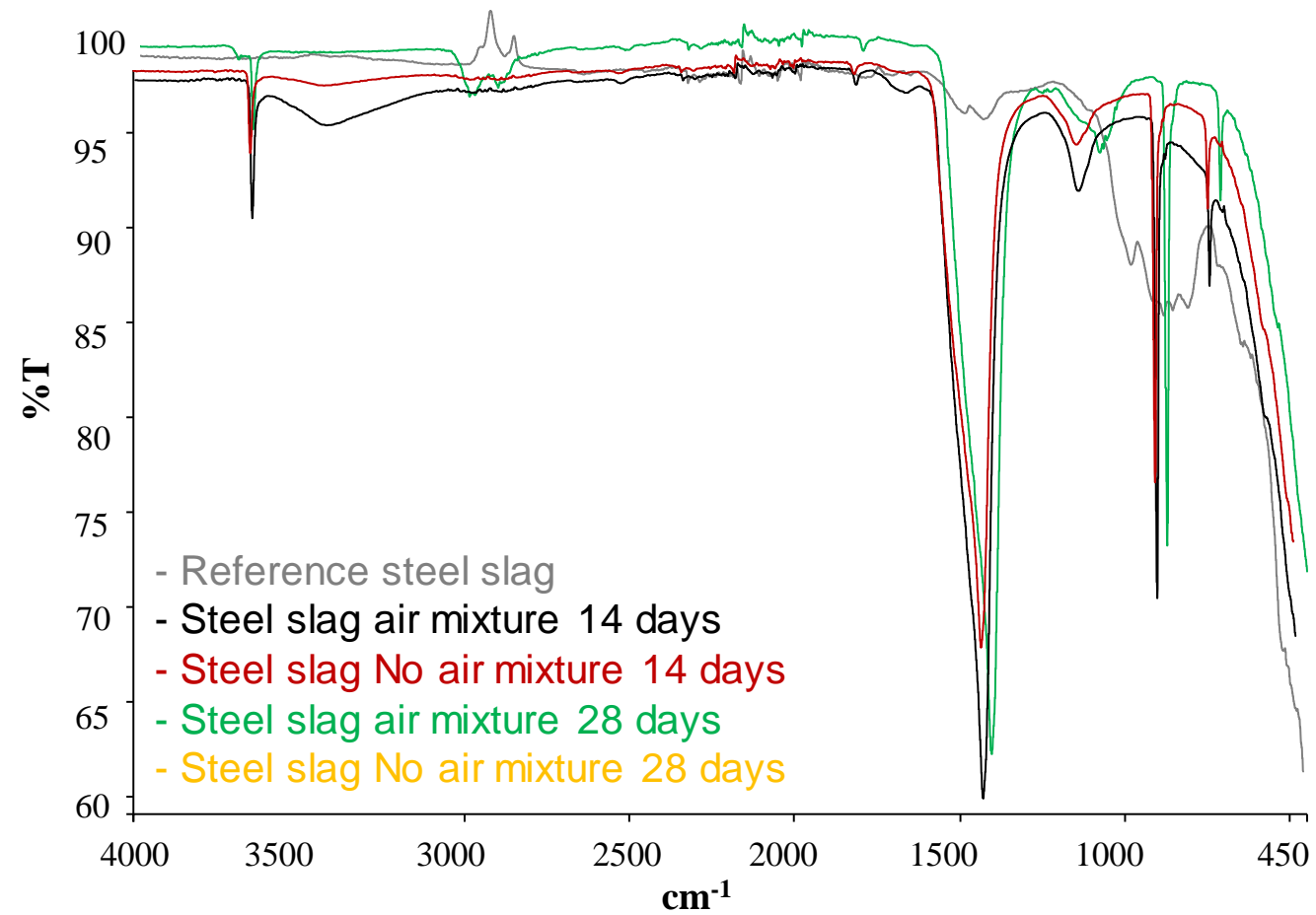

(e)

Figure 8. Cont. 


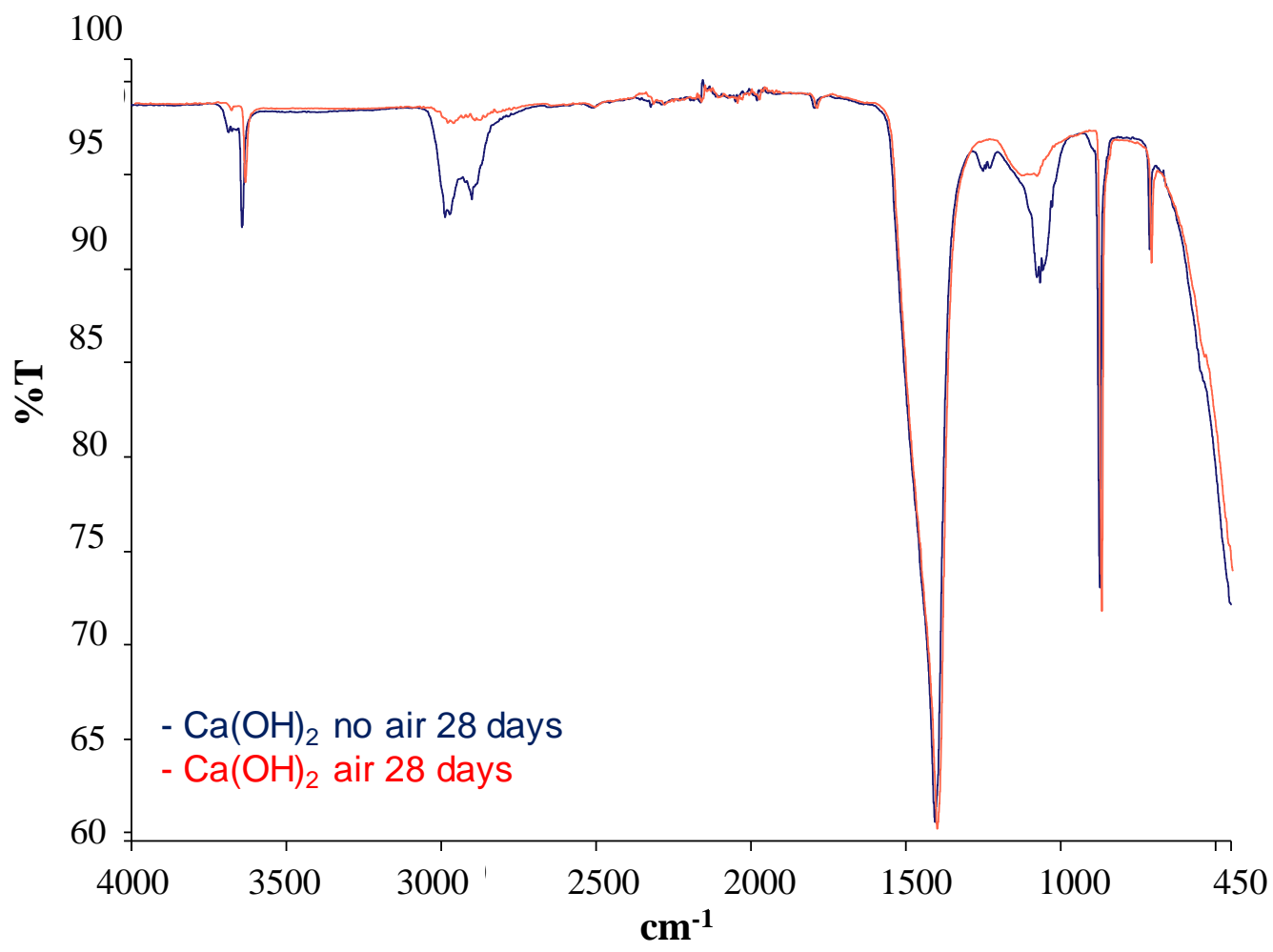

(f)

Figure 8. FT-IR for the pozzolanic test. (a) bauxite, $(\mathbf{b})$ chamotte, $(\mathbf{c})$ iron silicate, $(\mathbf{d})$ silica fume, $(\mathbf{e})$ steel slag, $(\mathbf{f}) \mathrm{Ca}(\mathrm{OH})_{2}$.

\subsection{Fibers}

When looking at the fibers using the optical microscope (Figure 9), the description found in the datasheets could be corroborated.

First, the changes seen in the fibers after 1 and 3 months under alkaline conditions were visually assessed. Figure 10 shows that metallic fibers RW50 and RW50+ present oxide in the surface after the immersion in the basic solution. After three months, the oxidation results were also present with a similar oxidation extent on the metal surface.

During the tensile strength testing, some difficulties were found in the shortest fibers since the jaws could not hold the fibers properly. While PP-ST42 and PP-CN54 fibers were tested, PP-ST30, NS12, NS18, all glass fibers (HD3, HD6, HD12, HP) and tire rubber fibers were impossible to test. From the datasheet of the manufacturer, the tensile strength of NS12 and NS18 is $400-500 \mathrm{~N} / \mathrm{mm}^{2}$. Unfortunately, for tire rubber no datasheet is available.

Figure 11 shows that before the $\mathrm{pH}$ test, MF-RW50+ has the highest tensile strength, $1442 \pm 200 \mathrm{MPa}$, while MF-RW50 the lowest, $557 \pm 15 \mathrm{MPa}$. Comparing the tensile strength provided by the company, MF-RW50 + has similar values while MF-RW50 does not reach the minimum tensile strength of $1000 \mathrm{MPa}$. After one month in $\mathrm{pH}$, all metal fibers had a slight tensile strength decrease. Whereas, after three months in $\mathrm{pH}, \mathrm{MF}-\mathrm{RW} 50+$ falls down its tensile strength to $1059 \pm 37 \mathrm{~N} / \mathrm{mm}^{2}$, having the same tensile strength as hooked fiber MF-PF. Despite the decrease observed in MF-RW50 +, tensile strength is still above the minimum of $850 \mathrm{MPa}$, provided in the company datasheet. 


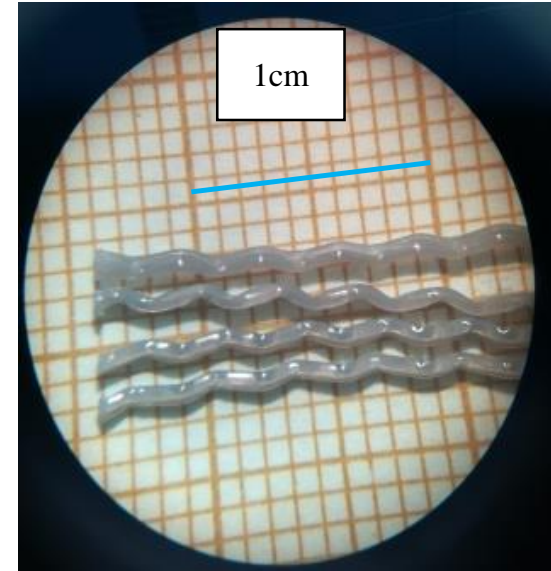

(a)

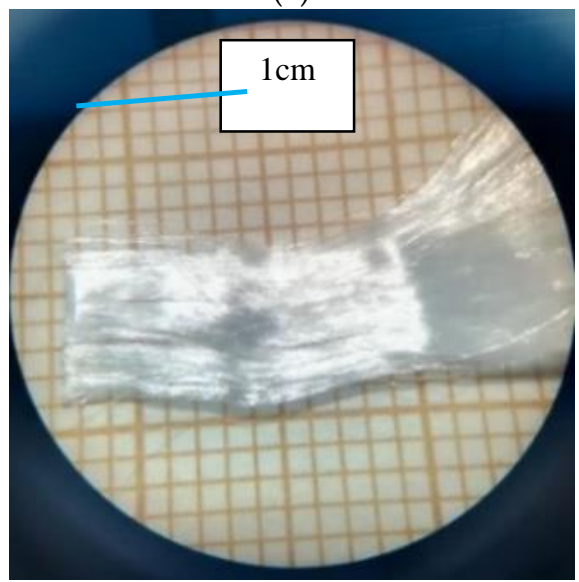

(d)

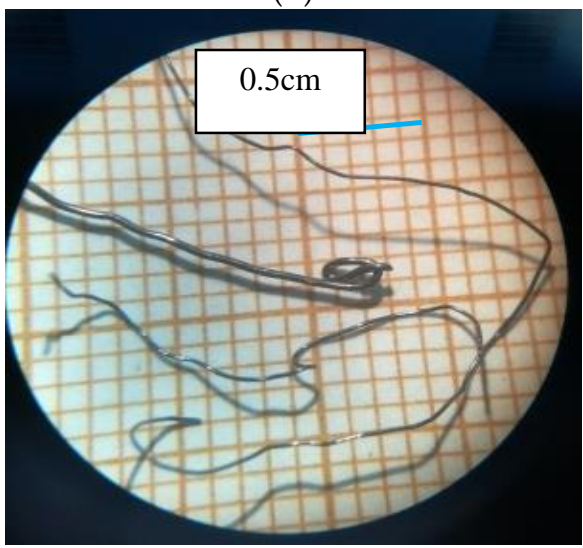

(g)

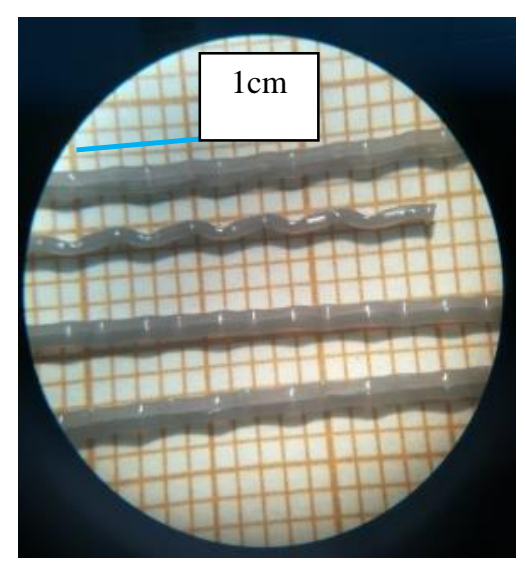

(b)

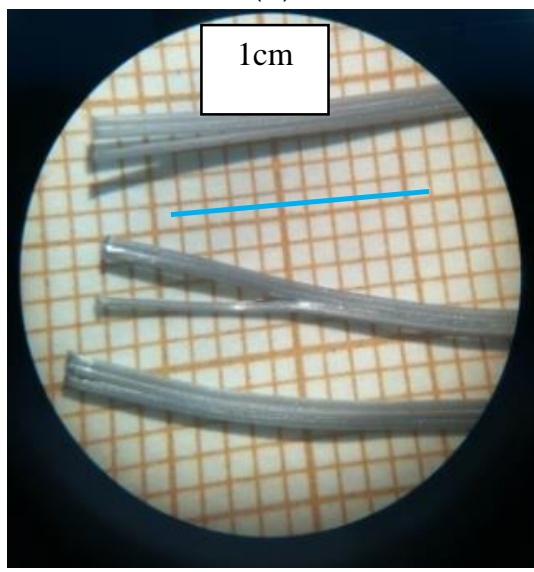

(e)

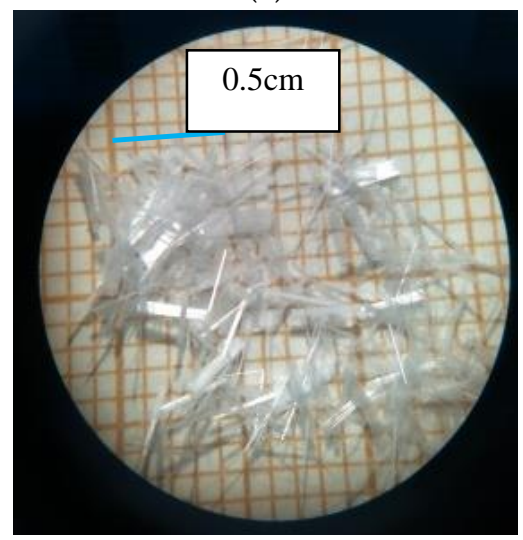

(h)

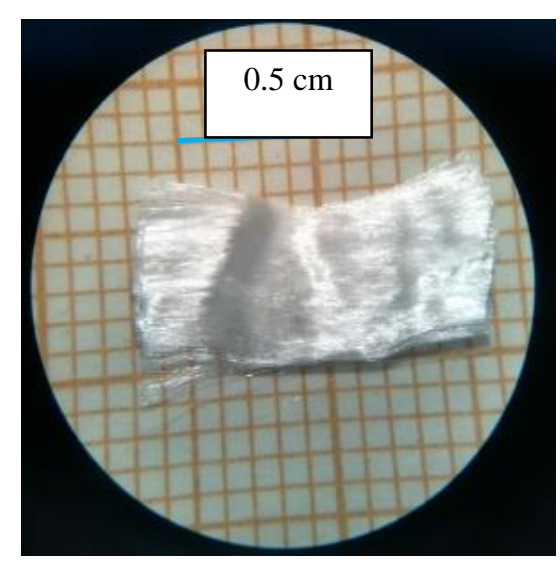

(c)

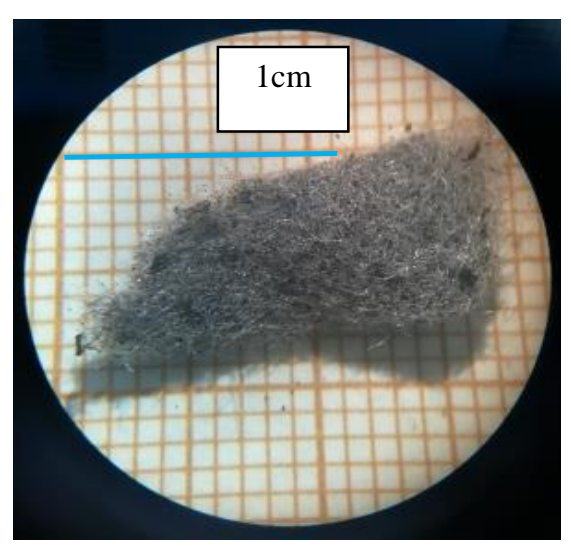

(f)

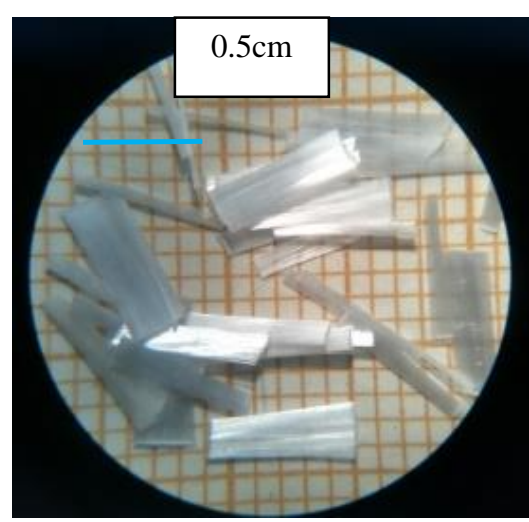

(i)

Figure 9. Cont. 


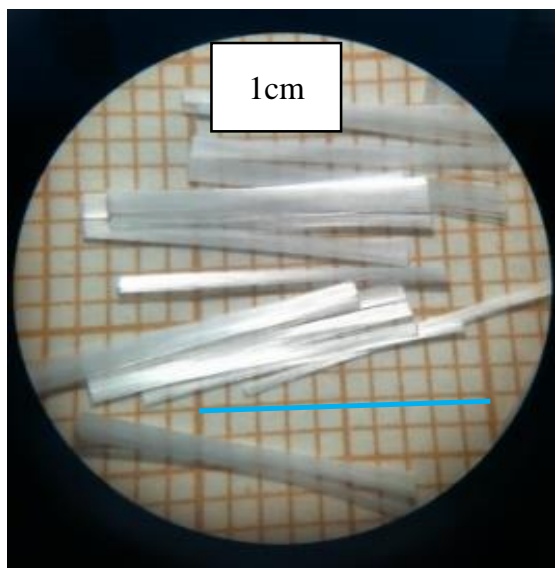

(j)

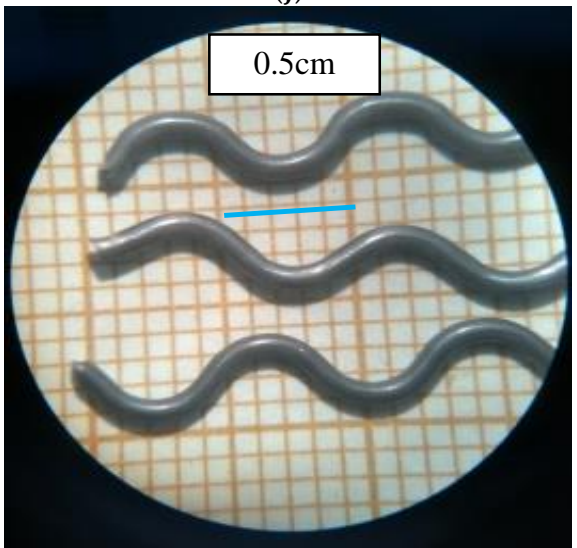

(m)

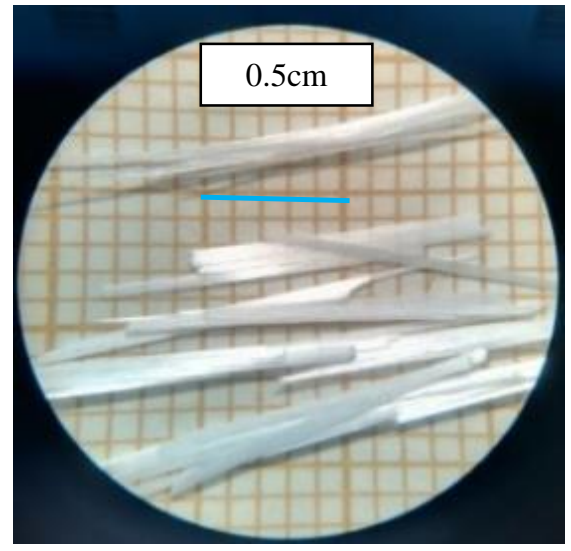

(k)

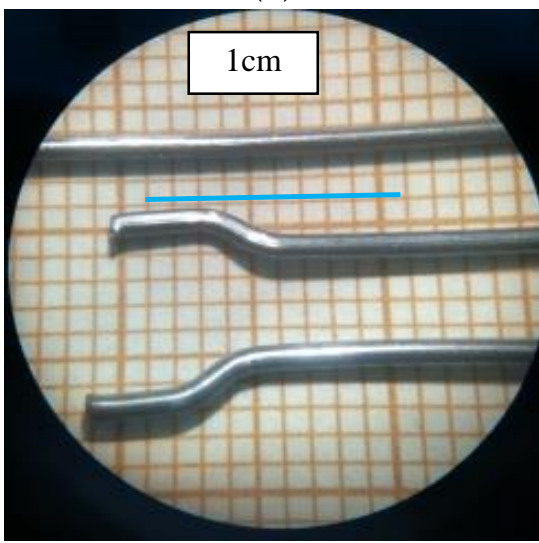

(n)

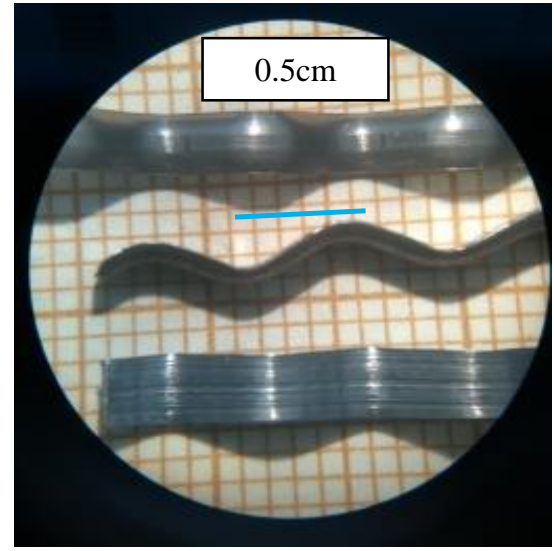

(1)

Figure 9. Type of fibers used in this research. Polypropylene fibers: (a) ST30, (b) ST42, (c) NS12, (d) NS18, (e) CN54. Pneumatic fibers: (f) pneumatic textile fiber (rubber), (g) steel fibers from pneumatic. Glass fibers: (h) HD3 (i) HD6 (j) HD12 (k) HP. Metal fibers: (1) RW50+, (m) RW50, (n) MF-FP.

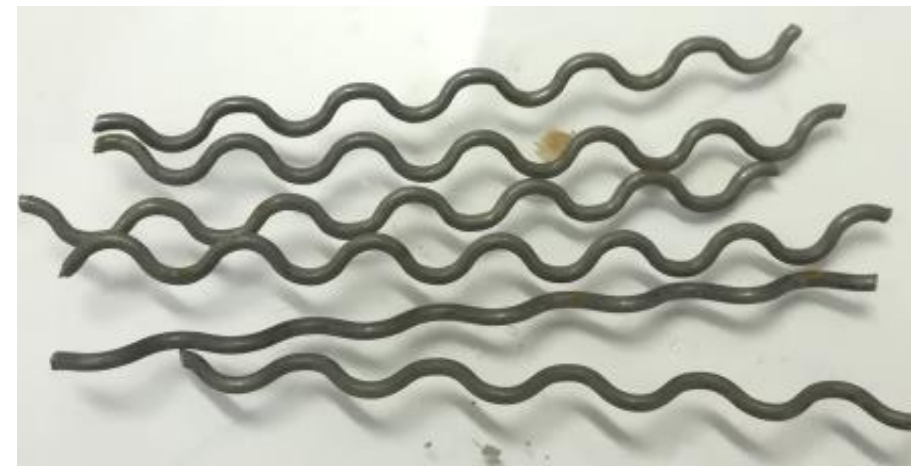

(a)

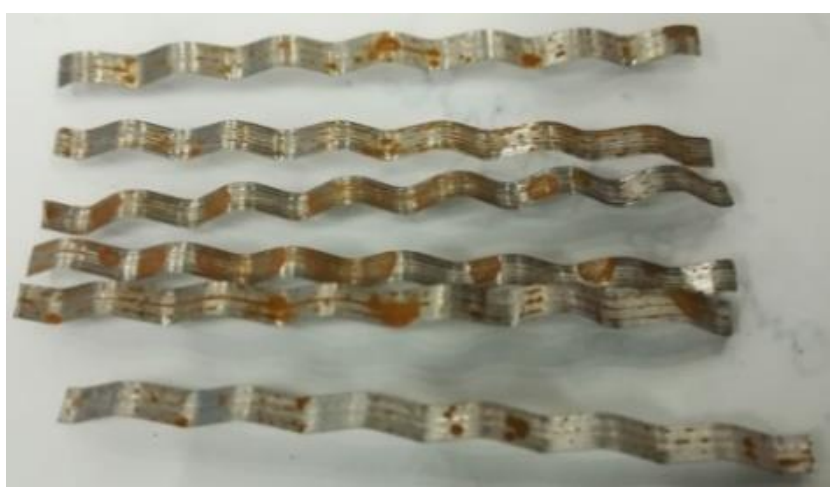

(b)

Figure 10. Fibers after one month of pH test. (a) RW50, and (b) RW50+. 


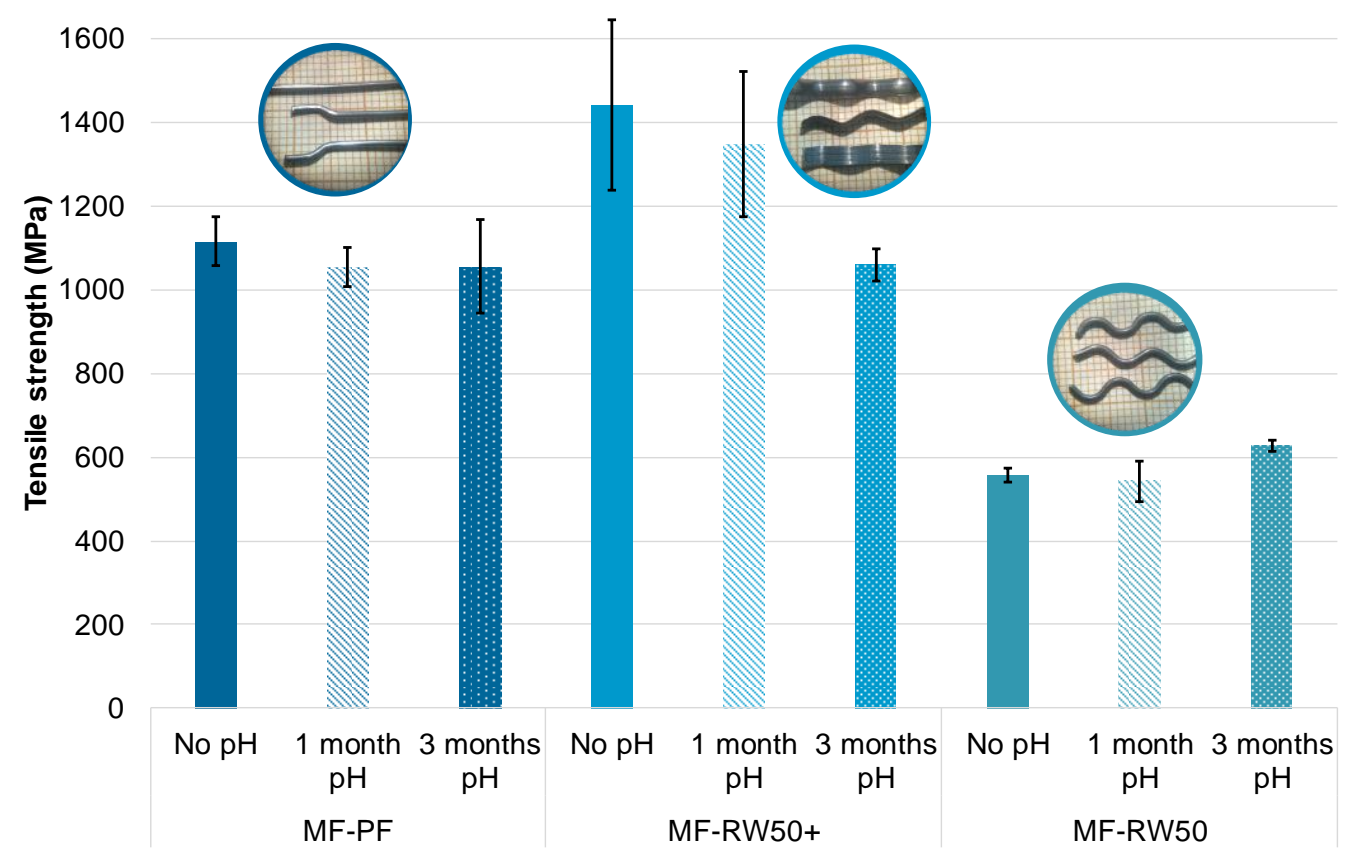

Figure 11. Tensile strength of metal fibers.

Figure 12 shows a wide variation of results with general decrease trend of tensile strength comparing fibers before $\mathrm{pH}$ test and after three months. The tested tensile strength results of both polypropylene fibers before any $\mathrm{pH}$ treatment are far lower than the ones provided by the company. After the first month of exposure to $\mathrm{pH}$, the PP fibers report a strength recovery. However, after three months, the tensile strength is nearly equal to fibers without being exposed to $\mathrm{pH}$.

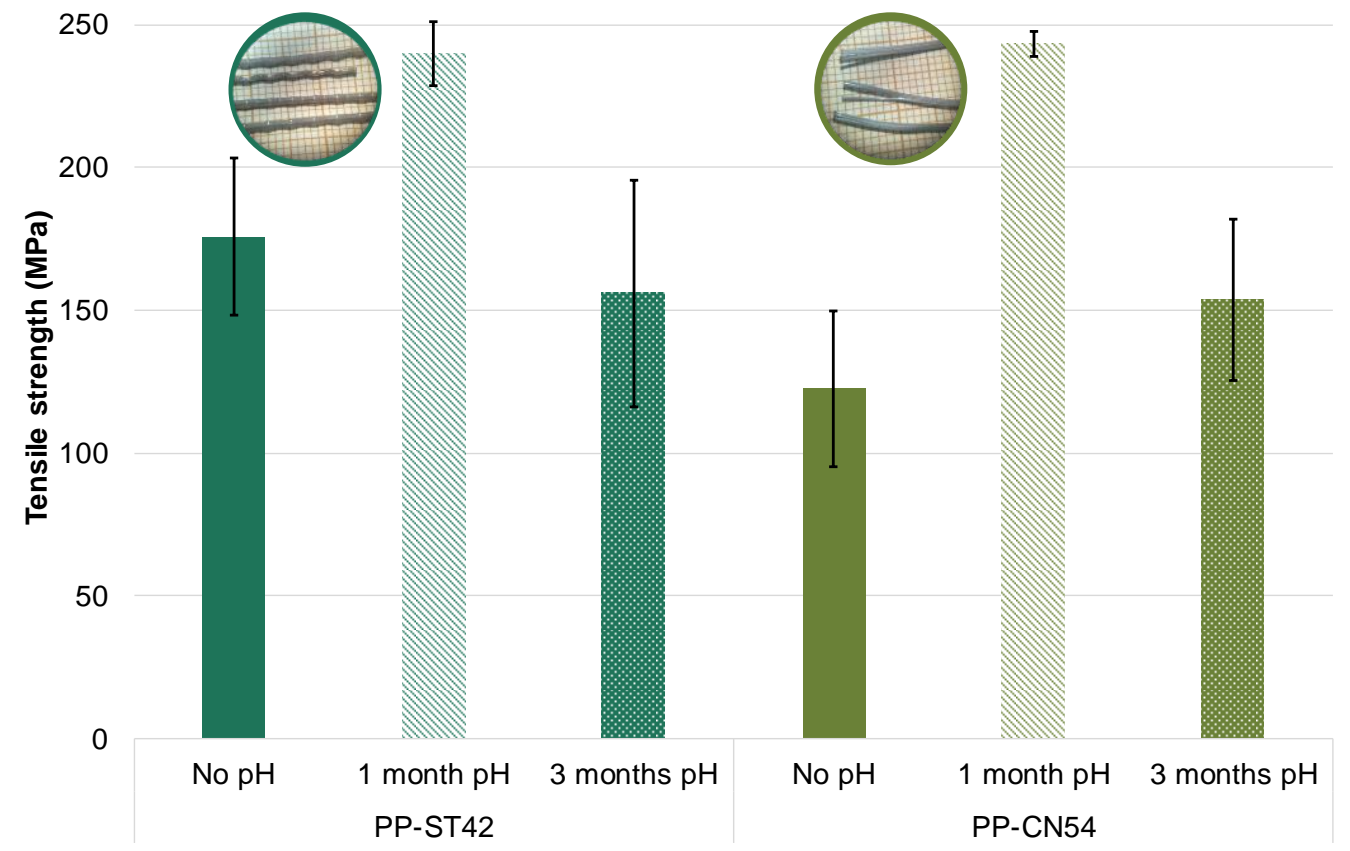

Figure 12. Tensile strength of polypropylene fibers.

Similar findings were reported by Micelli et al. [44], showing that tensile strength in different fibers decreases after exposure to alkaline environments and temperatures. Also, 
Stepanek et al. [45] performed a long-term glass fiber exposure and concluded that tensile strength decreased while elastic modulus is not highly affected.

Polypropylene fibers IRs spectra can be seen in Figure 13. The five PP fibers are plotted together to compare them. As it can be seen they are quite similar. The obtained PP fibers spectrums were similar to the ones reported by other researchers [46]. Concerning glass fibers, the IR's results show that all types of glass fibers are very similar. Like the polypropylene fibers, glass fibers present nearly the same spectrum corresponding to glass fiber [47]. The pneumatic fibers FT-IR correspond to a polyester fiber, in accordance with other authors' research [48].

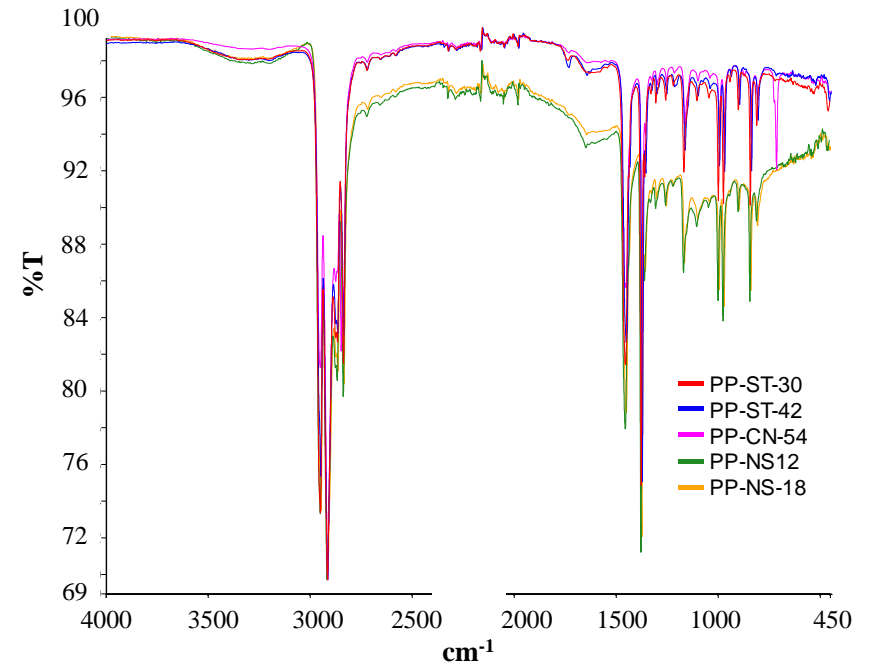

(a)

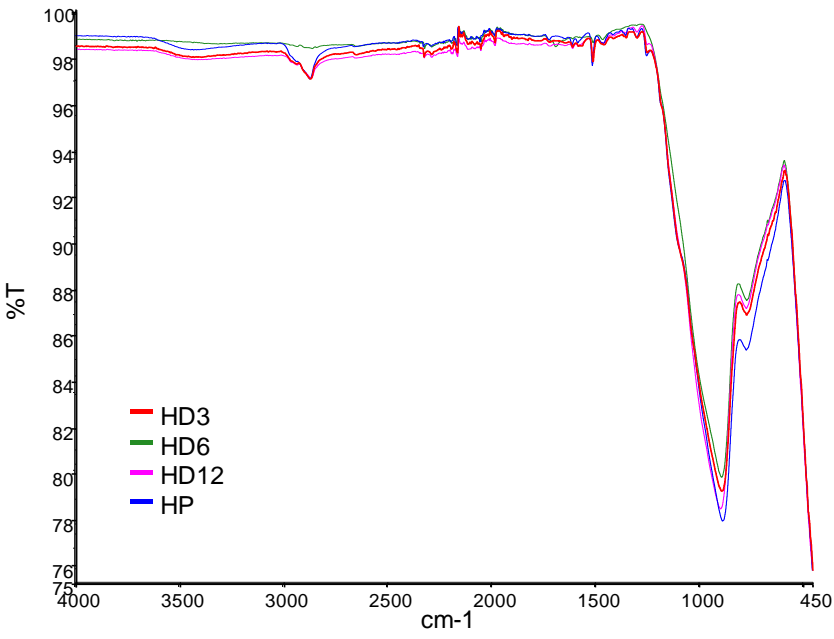

(b)

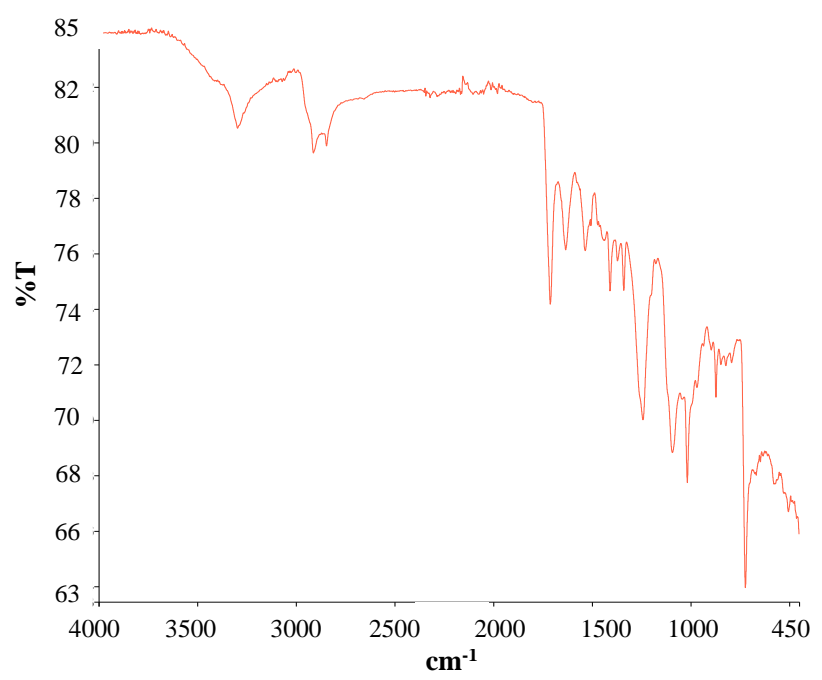

(c)

Figure 13. FT-IR of fibers. (a) Polypropylene fibers; (b) glass fibers; (c) pneumatic textile fibers.

\section{Conclusions}

This paper evidences the literature gaps in identifying and selecting supplementary cementitious materials and fibers to be incorporated in concrete, within the frame of thermal energy storage under high-temperature conditions. As an onset, this study aimed to select and characterize different SCM and fibers available in the market, showing their possible compatibility with concrete to be used as TES material, for instance, in a CSP plant. 
Concerning the supplementary cementitious analysis, XRD results showed that bauxite and chamotte have crystalline phases, while the others are more amorphous. Moreover, in the pozzolanic test, analyzed through FT-IR, the formation of CSH (tobermorite) was observed after the test in all the supplementary cementitious materials. The presence of calcium silicate hydrate gel ensures the pozzolanic activity, which gives the selected SCM the capability to react with calcium hydroxide forming hydraulic compounds. This reaction is possible when adding SCM to Portland cement to form cementing matrix with portlandite. On the other hand, the particle size inspection showed that most of the SCM should have a further grinded treatment to be incorporated as a partial replacement of cement and increase the pozzolanic activity.

In the $\mathrm{pH}$ test some fibers showed some oxide in the surface. The polymeric, tire, and glass fibers were more difficult to test than the metal ones. Despite the accurate procedure carried out during the test, some complications came across while performing the tensile test. The fibers shorter than $2 \mathrm{~cm}$, were too tiny to hold them with the jaws, not being able to measure the tensile strength to them. Moreover, some measures were not significant since the samples slipped and cracked from the jaws and not from the center of the sample.

It was noticed that the shape of the fibers could be determinant with their tensile resistance. For example, the wave-shaped polypropylene fibers have higher tensile strength than the straight shape ones. Even a shaved-wave fiber without the $\mathrm{pH}$ test has higher tensile strength than a $\mathrm{pH}$ test sample with a straight shave. A different structure, crystallinity, or orientations in the processing of these materials are other reasons for the possible tensile strength changes.

After one and three months in a basic $\mathrm{pH}$ solution, polymeric fibers showed a considerable dispersion in tensile strength. Concerning metal fibers, the greater decrease in tensile strength is in the thicker fiber MF-RW50+. This tensile strength loss suggests that it can influence the early ages of concrete chemical hardening process.

Additional studies are much needed, bracing ourselves for the next SCM generation and their compatibility with different cement types, evaluating the fresh and hardened state properties. A particular concern within the thermal energy storage field should be paid in thermo-mechanical results when incorporating SCM in cementitious mixtures.

Author Contributions: Conceptualization, L.F.C. and A.I.F.; Methodology, L.F.C. and A.I.F.; Formal analysis, L.F.C. and A.I.F.; Investigation, L.B. and D.P.; Resources, L.F.C.; Data curation, L.F.C.; Writing-original draft preparation, L.B. and D.P.; Writing-review and editing, L.F.C. and A.I.F.; Visualization, L.B.; Supervision, L.F.C. and A.I.F.; Project administration, L.F.C. and A.I.F.; Funding acquisition, L.F.C. All authors have read and agreed to the published version of the manuscript.

Funding: This work was partially funded by the Ministerio de Ciencia, Innovación y Universidades de España (RTI2018-093849-B-C31-MCIU/AEI/FEDER, UE and RTI2018-093849-B-C32$\mathrm{MCIU} / \mathrm{AEI} / \mathrm{FEDER}$ ) and by the Ministerio de Ciencia, Innovación y Universidades-Agencia Estatal de Investigación (AEI) (RED2018-102431-T). This work is partially supported by ICREA under the ICREA Academia programme. This study was partially funded by AEI-Spanish Ministry of Science, Innovation and Universities (PCI2020-120695-2/AEI/10.13039/501100011033 and PCI2020-1206822/ AEI/10.13039/501100011033 through PCI call).

Institutional Review Board Statement: Not applicable.

Informed Consent Statement: Not applicable.

Data Availability Statement: The data is available from the correspondence author under request.

Acknowledgments: The authors would like to thank the Catalan Government for the quality accreditation given to their research groups (2017 SGR 1537 and 2017 SGR 118). GREiA and DIOPMA are certified agents TECNIO in the category of technology developers from the Government of Catalonia. The authors also thank the companies that provided the material to make possible this experimental research: Gestión Medioambiental de Neumáticos S.L., Arciresa, EDERSA-Masaveu Industria and Promsa-Megasa.

Conflicts of Interest: The authors declare no conflict of interest. 


\section{References}

1. Martins, F.; Felgueiras, C.; Smitkova, M.; Caetano, N. Analysis of fossil fuel energy consumption and environmental impacts in european countries. Energies 2019, 12, 964. [CrossRef]

2. Kabir, E.; Kumar, P.; Kumar, S.; Adelodun, A.A.; Kim, K.H. Solar energy: Potential and future prospects. Renew. Sustain. Energy Rev. 2018, 82, 894-900. [CrossRef]

3. Bórawski, P.; Yashchenko, T.; Sviderskyi, A.; Dunn, J.W. Development of renewable energy market in the EU with particular regard to solar energy. Conf. Proc. Determ. Reg. Dev. 2019, 43-55. [CrossRef]

4. Medrano, M.; Gil, A.; Martorell, I.; Potau, X.; Cabeza, L.F. State of the art on high-temperature thermal energy storage for power generation. Part 2-Case studies. Renew. Sustain. Energy Rev. 2010, 14, 56-72. [CrossRef]

5. Gil, A.; Medrano, M.; Martorell, I.; Lázaro, A.; Dolado, P.; Zalba, B.; Cabeza, L.F. State of the art on high temperature thermal energy storage for power generation. Part 1-Concepts, materials and modellization. Renew. Sustain. Energy Rev. 2010, 14, 31-55. [CrossRef]

6. Fernández, A.G.; Gomez-Vidal, J.; Oró, E.; Kruizenga, A.; Solé, A.; Cabeza, L.F. Mainstreaming commercial CSP systems: A technology review. Renew. Energy 2019, 140, 152-176. [CrossRef]

7. González-Roubaud, E.; Pérez-Osorio, D.; Prieto, C. Review of commercial thermal energy storage in concentrated solar power plants: Steam vs. molten salts. Renew. Sustain. Energy Rev. 2017, 80, 133-148. [CrossRef]

8. Khare, S.; Dell'Amico, M.; Knight, C.; McGarry, S. Selection of materials for high temperature sensible energy storage. Sol. Energy Mater. Sol. Cells 2013, 115, 114-122. [CrossRef]

9. Laing, D.; Bahl, C.; Bauer, T.; Fiss, M.; Breidenbach, N.; Hempel, M. High-temperature solid-media thermal energy storage for solar thermal power plants. Proc. IEEE 2012, 100, 516-524. [CrossRef]

10. John, E.E.; Hale, W.M. Effect of High Temperatures and Heating Rates on High Strength. Energy Sustain. 2010, 43956, 709-713.

11. Lothenbach, B.; Scrivener, K.; Hooton, R.D. Supplementary cementitious materials. Cem. Concr. Res. 2011, 41, 1244-1256. [CrossRef]

12. Snellings, R.; Mertens, G.; Elsen, J. Supplementary cementitious materials. Rev. Mineral. Geochem. 2012, 74, 211-278. [CrossRef]

13. Juenger, M.C.G.; Snellings, R.; Bernal, S.A. Supplementary cementitious materials: New sources, characterization, and performance insights. Cem. Concr. Res. 2019, 122, 257-273. [CrossRef]

14. CEN (European Committee for Standarization). EN-197. 1 Cement Composición, Especificaciones y Criterios de Conformidad de los Cementos Comunes; CEN (European Committee for Standarization): Brussels, Belgium.

15. Snellings, R. Assessing, Understanding and Unlocking Supplementary Cementitious Materials. RILEM Tech. Lett. 2016, 1, 50. [CrossRef]

16. John, E.; Hale, M.; Selvam, P. Concrete as a thermal energy storage medium for thermocline solar energy storage systems. Sol. Energy 2013, 96, 194-204. [CrossRef]

17. Pan, J.; Zou, R.; Jin, F. Experimental study on specific heat of concrete at high temperatures and its influence on thermal energy storage. Energies 2017, 10, 33. [CrossRef]

18. Wu, C.; Pan, J.; Zhong, W.; Jin, F. Testing of high thermal cycling stability of low strength concrete as a thermal energy storage material. Appl. Sci. 2016, 6, 271. [CrossRef]

19. Alonso, M.C.; Vera-Agullo, J.; Guerreiro, L.; Flor-Laguna, V.; Sanchez, M.; Collares-Pereira, M. Calcium aluminate based cement for concrete to be used as thermal energy storage in solar thermal electricity plants. Cem. Concr. Res. 2016, 82, 74-86. [CrossRef]

20. El-Sharkawy, H.; El Bably, M.; Omar, I.; Adel, R.; Gendy, R.; Minass, A.; Fathy, A.; Abou-Zeid, M.N.; Fahmy, E. Thermal storage concrete. In Proceedings of the 2015 CSCE Annual Conference, Regina, SK, Canada, 27-30 May 2015; pp. 1-10.

21. Chengzhou, G.; Jiaoqun, Z.; Weibing, Z.; Wen, C. Fabrication and thermal properties of a new heat storage concrete material. J. Wuhan Univ. Technol. Sci. Ed. 2010, 25, 628-630. [CrossRef]

22. Gil, A.; Calvet, N.; Ortega, I.; Risueño, E.; Faik, A.; Rodríguez-aseguinolaza, J. Characterization of a by-product from steel industry applied to thermal energy storage in Concentrated Solar Power. Proc. Eurotherm Semin. 2014, 99, 1-9.

23. Ortega-Fernández, I.; Calvet, N.; Gil, A.; Rodríguez-Aseguinolaza, J.; Faik, A.; D'Aguanno, B. Thermophysical characterization of a by-product from the steel industry to be used as a sustainable and low-cost thermal energy storage material. Energy 2015, 89, 601-609. [CrossRef]

24. Miró, L.; Navarro, M.E.; Suresh, P.; Gil, A.; Fernández, A.I.; Cabeza, L.F. Experimental characterization of a solid industrial by-product as material for high temperature sensible thermal energy storage (TES). Appl. Energy 2014, 113, 1261-1268. [CrossRef]

25. Gutierrez, A.; Miró, L.; Gil, A.; Rodríguez-Aseguinolaza, J.; Barreneche, C.; Calvet, N.; Py, X.; Fernández, A.I.; Grágeda, M.; Ushak, S.; et al. Advances in the valorization of waste and by-product materials as thermal energy storage (TES) materials. Renew. Sustain. Energy Rev. 2016, 59, 763-783. [CrossRef]

26. Cánovas, M.F. Hormigones con fibras: Tecnología y propiedades generales. Hormigón y Acero 2003, 54, 167-176.

27. ACI. ACI Committee 544 1R, Report on Fiber Reinforced Concretes; ACI: Indianapolis, IN, USA, 1996.

28. Romualdi, J.P.; Batson, G.B. Mechanics of Crack Arrest in Concrete. J. Eng. Mech. ASCE 1963, 89, 147-168.

29. Biryukovich, K.L.; Yu, D.L. Glass Fiber Reinforced Cement. Civ. Eng. Res. Assoc. 1965, 41.

30. Ma, Q.; Guo, R.; Zhao, Z.; Lin, Z.; He, K. Mechanical properties of concrete at high temperature-A review. Constr. Build. Mater. 2015, 93, 371-383. [CrossRef] 
31. Ozger, O.B.; Girardi, F.; Giannuzzi, G.M.; Salomoni, V.A.; Majorana, C.E.; Fambri, L.; Baldassino, N.; Di Maggio, R. Effect of nylon fibers on mechanical and thermal properties of hardened concrete for energy storage systems. Mater. Des. 2013, 51, 989-997. [CrossRef]

32. Girardi, F.; Giannuzzi, G.M.; Mazzei, D.; Salomoni, V.; Majorana, C.; Di Maggio, R. Recycled additions for improving the thermal conductivity of concrete in preparing energy storage systems. Constr. Build. Mater. 2017, 135, 565-579. [CrossRef]

33. Ríos, J.D.; Cifuentes, H.; Leiva, C.; García, C.; Alba, M.D. Behavior of high-strength polypropylene fiber-reinforced self-compacting concrete exposed to high temperatures. J. Mater. Civ. Eng. 2018, 30, 1-13. [CrossRef]

34. Adeyanju, A.A.; Manohar, K. Effects of Steel Fibers and Iron Filings on Thermal and Mechanical Properties of Concrete for Energy Storage Application. J. Miner. Mater. Charact. Eng. 2011, 10, 1429-1448. [CrossRef]

35. Adeyanju, A.A.; Manohar, K. Effects of steel fibers on properties of concrete for energy storage application. J. Eng. Appl. Sci. 2011, 6, 336-345. [CrossRef]

36. John, E.E.; Hale, W.M.; Brown, B. Development and Performance Evaluation of High Temperature. In Proceedings of the ASME 2011 International Mechanical Engineering Congress and Exposition, Denver, CO, USA, 11-17 November 2011; 2011; pp. 1-7. [CrossRef]

37. Ghafari, E.; Feys, D.; Khayat, K. Feasibility of using natural SCMs in concrete for infrastructure applications. Constr. Build. Mater. 2016, 127, 724-732. [CrossRef]

38. Thomas, M. The effect of supplementary cementing materials on alkali-silica reaction: A review. Cem. Concr. Res. 2011, 41, 1224-1231. [CrossRef]

39. European Center for Standarization. EN-12698-2. Chemical Analysis of Nitride Bonded Silicon Carbide Refractories; Part 2. XRD methods; European Center for Standarization: Brussels, Belgium, 2007; pp. 1-18.

40. AENOR. UNE 53934:2016. Plásticos. Análisis Elemental en Materiales Poliméricos por el Método de Fluorescencia por Rayos X; AENOR: Madrid, Spain, 2016.

41. Wang, S.; Peng, X.; Tang, L.; Zeng, L.; Lan, C. Influence of inorganic admixtures on the 11 A-tobermorite formation prepared from steel slags: XRD and FTIR analysis. Constr. Build. Mater. 2014, 60, 42-47. [CrossRef]

42. AENOR. UNE 40-248-75. Método para el Ensayo de Tracción. Dinamometria de Hace Planos de Fibras de lana; AENOR: Madrid, Spain, 1975; Volume 75.

43. ASTM (D638). American Society for Testing and Materials. Standard Test Method for Tensile Properties of Plastics (D 638-02a)—SCAN VERSION; ASTM: West Conshohocken, PA, USA, 2003; Volume 8, pp. 46-58. [CrossRef]

44. Micelli, F; Aiello, M.A. Residual tensile strength of dry and impregnated reinforcement fibers after exposure to alkaline environments. Compos. Part B Eng. 2019, 159, 490-501. [CrossRef]

45. Stepanek, P.; Janus, O.; Girgle, F.; Bodnarova, L.; Kostiha, V.; Rozsypalova, I. Long term strength of internal GFRP reinforcement by alkaline, temperature and cyclic loading. Procedia Struct. Integr. 2018, 11, 12-19. [CrossRef]

46. Barbeş, L.; Rădulescu, C.; Stihi, C. ATR-FTIR spectrometry characterization of polymeric materials. Rom. Rep. Phys. 2014, 66, 765-777.

47. Morales, A.; Pérez, G.F. Caracterización por espectroscopía en el infrarrojo de óxidos de silicio depositados en ambiente de $\mathrm{N}_{2} \mathrm{O}$. Superf. Y Vacío 2003, 16, 16-18.

48. Cecen, V.; Seki, Y.; Sarikanat, M.; Tavman, I.H. FTIR and SEM analysis of polyester- and epoxy-based composites manufactured by VARTM process. J. Appl. Polym. Sci. 2008, 108, 2163-2170. [CrossRef] 